\title{
Assessment of the Governance Dimension in the Frame of the 2030 Agenda: Evidence from 100 Spanish Cities
}

\author{
Carmen García-Peña ${ }^{1, *}$, Moneyba González-Medina ${ }^{2}\left(\mathbb{D}\right.$ and Jose Manuel Diaz-Sarachaga ${ }^{3}$ (D) \\ 1 Economic and Business Programme, Department of Applied Economics (Economic Policy), \\ Universidad de Málaga, 29013 Málaga, Spain \\ 2 Department of Political Science and International Relations, Universidad Autónoma de Madrid, \\ 28049 Madrid, Spain; moneyba.gonzalez@uam.es \\ 3 GTDS Research Group, Faculty of Law, Universidad de Oviedo, 33006 Oviedo, Spain; \\ jmdsarachaga@hurbannia.com \\ * Correspondence: carmengarciap@uma.es
}

check for updates

Citation: García-Peña, C.; GonzálezMedina, M.; Diaz-Sarachaga, J.M. Assessment of the Governance Dimension in the Frame of the 2030 Agenda: Evidence from 100 Spanish Cities. Sustainability 2021, 13, 5519. https://doi.org/10.3390/su13105519

Academic Editors: Clemente

J. Navarro Yáñez and María Jesús Rodríguez-García

Received: 2 April 2021

Accepted: 10 May 2021

Published: 14 May 2021

Publisher's Note: MDPI stays neutral with regard to jurisdictional claims in published maps and institutional affiliations.

Copyright: (c) 2021 by the authors. Licensee MDPI, Basel, Switzerland. This article is an open access article distributed under the terms and conditions of the Creative Commons Attribution (CC BY) license (https:/ / creativecommons.org/licenses/by/ $4.0 /)$.

\begin{abstract}
The 2030 Agenda highlights the importance of governance to achieve Sustainable Development Goals (SDG). However, we observe that there is an underestimation of the governance dimension in the SDG indices. The reasons are twofold. Firstly, indices assign a lower weight to governance compared to the other dimensions of sustainability. Secondly, most governance indicators do not measure the relational dynamics that underlie sustainable development policies. The aim of this study is thus to provide alternative methods for a more accurate assessment of the governance dimension in the frame of the 2030 Agenda. With this purpose, we examine the performance of 100 Spanish cities on the SDGs included in the first report elaborated by the Sustainable Development Solutions Network Spain in 2018. Using this data, we first develop a methodology to rebalance the current underestimation of the governance dimension, comparing its impact on the SDG performance of these cities. Secondly, we build a new indicator of 'Strategic Culture' to get a more accurate measure of governance in urban contexts. As a result, the study validates the proposed methods and provides evidence that better performance on sustainable development is favored by the implementation of strategic planning processes.
\end{abstract}

Keywords: sustainable development; governance; SDG index; policy evaluation; strategic planning processes; Spanish cities

\section{Introduction}

There is a prolific debate about the core meaning of 'sustainable development' (SD) and 'governance', and how to measure them [1-3]. On the one hand, SD has been defined as "the development that meets needs of current generation without compromising the ability of future generations to meet their own needs" [4]. However, despite this definition constituting an important milestone, it is rather vague in terms of policy development. On the other hand, there is no universally agreed upon definition of governance. This notion is based on the idea that the nature of the state has changed [5,6], so 'governance' differs from 'government', but it is a central component of it. The latter refers to the institutions and actions of the state, while the former goes further and stresses the relational dynamics between different stakeholders that underlie policymaking processes [7].

The manner in which SD and governance are defined within a policy frame (e.g., the 2030 Agenda) has important consequences in terms of evaluation. Complex concepts like these need to be decomposed into different dimensions, which are assessed by means of an assigned set of indicators. In this sense, SD has traditionally been operationalized in three dimensions (society, environment, and economy). However, 'governance' as a fourth dimension has gained importance over time, becoming part of the concept of SD itself $[8,9]$. In fact, the five pillars of the 2030 Agenda correspond to the four dimensions of SD, namely: 
society (people), environment (planet), economy (prosperity), and governance (peace and partnership). Nevertheless, when these dimensions are translated into composite indices, the governance dimension usually appears underestimated and oversimplified.

As regards indicators, Bertelsmann Stiftung and the Sustainable Development Solution Network (SDSN) compile most of the indicators tied to the 2030 Agenda in a 'SDG Index' that is published annually [10]. SDSN is the body supported by the UN Secretary-General to mobilize global scientific and technological expertise to promote the implementation of the SDGs. The Spanish branch of SDSN is 'REDS' (Spanish Sustainable Development Network), which oversees the monitoring of the 2030 Agenda at the city level in this country. Despite their effort to identify suitable indicators, however, those assigned to the governance dimension usually represent a narrow interpretation of the term that is primarily conditioned by data availability. Therefore, most relevant SDG indices at the country level [11-13] appraise governance in a simplified manner.

Against this backdrop, we develop a four-step method to assess the governance dimension in the context of the 2030 Agenda upon the data collected from the first REDS report on the achievement of the SDGs for 100 Spanish cities [14]. Our main purpose is to empirically demonstrate the underestimation of this dimension in SDG composite indices using this data. Firstly, we test different methods to measure governance and compare their impact on the SD performance of the 100 Spanish cities. Secondly, we evaluate the set of governance indicators selected by REDS taking as reference the operational definition of governance proposed by Glass and Newig [3].

The comparison of cities allows us to check our hypothesis and methods empirically, leading us to propose a correction of the weighting factor assigned to the governance dimension in the REDS-SDG Index, and to build a new governance indicator called 'Strategic Culture' (Icu). This new indicator provides information about the governance dynamics that underlie SD policies in cities and that are usually missing in the set of governance indicators included in composite indices. Hereby, the analysis advances significant results regarding the measurement of the governance dimension in terms of coherence and consistency within the REDS-SDG Index, but also about the relationship between governance and performance on SD.

The article presents the theorical framework in Section 2 and introduces the methods developed to assess the SDG and the governance dimension. Our methodology to improve the actual proposals of indices and compare the performance of the 100 Spanish cities is in Section 3. Section 4 presents the results regarding (a) influence of methods employed to measure governance in the ranking of cities in terms of SDG performance; (b) adequacy of the governance indicators; and (c) validity of the governance indicator 'Strategic Culture'. Advantages of the multidimensional analysis compared to the approach used by SDG indices and the pertinence of considering strategic planning processes as governance indicators are discussed in Section 5. The main contributions of this research and future development are summarized in the last section.

\section{Theoretical Framework}

Our theoretical framework has been built upon several studies on integrated urban sustainable development policies from different fields of knowledge. In the following subsections, we particularly focus on the literature about governance, policy integration, strategic planning, and indicators of sustainable development, with particular attention to the relation among them.

\subsection{Governance, Policy Integration, Strategic Planning, and Sustainable Development}

Governance, policy integration, strategic planning, and SD are interrelated notions. SD is considered a 'wicked problem' [15], namely, a particularly challenging problem that transcends the borders of traditional policy domains, involves a wide variety of actors at different scale levels, and is reluctant to be solved. The more 'wicked' the issue, the more policy integration is needed in terms of collaboration, cooperation, and coordination of 
actors and actions. All these elements are embedded in the notion of governance, and strategic planning (SP) is explicitly aimed at managing all of them.

The literature emphasizes the relational nature of governance by providing a broad definition as "the totality of interactions, in which government, other public bodies, private sector and civil society participate, aiming at solving societal problems or creating societal opportunities" [16] (p. 12198). In this regard, the implementation of SD policies has traditionally been supported by strategic planning processes such as the Local Agenda 21, Urban Strategic Plans, and so on, which foster both policy coherence and stakeholder participation according to a comprehensive and holistic approach towards SD [16-18].

Policy integration is determined as a prerequisite of policy success in the frame of SD policies and the 2030 Agenda represents an ambitious effort to achieve it [18], alongside the Integrated Sustainable Urban Development (ISUD) approach adopted by the European Union (EU) [19-21]. Del Castillo and Haarich [21] state that the principle of 'integrated' urban development is mainly referred to the planning and management aspects, while the 'sustainable' is linked to objectives, topics, and areas of intervention towards urban development. However, both concepts go together in practice, as SD does not just happen in an automatic way, but needs to be carefully discussed, openly debated, and planned [22,23].

In this vein, the aim of SP is to mobilize a plurality of actors with different or even competing interests towards a common vision of development $[24,25]$. SP is related to the establishment of networks of cooperation through integrated planning [26], and seeks to provide an effective working method to achieve coherence and drive the 'organizing capacity' of a territory, which is defined as the ability to convene stakeholders to jointly generate new ideas, formulate and implement policies for achieving community goals, and create the conditions for SD [27].

According to Healey [28], three concepts run through discussions of urban governance and into SP, namely: multi-level governance, partnership, and participation. In fact, SP moves away from the idea of government as a mobilizer of the public sector and provider of solutions to problems, towards an idea of governance through the mobilization of a plurality of actors. This planning approach is becoming mainstream in the urban development policy domain [29], and a standard across Europe [30,31]. This approach was proposed at the informal meeting of the European Ministers of Urban Development, held in the German city of Leipzig in 2007 [32], but it was already widely used before [33-35]. Nowadays, SP constitutes one of the three core elements-together with scale and stakeholders-that structure the OECD Principles of Urban Policy [36,37]. The main objective of SP is thus to address the economic, environmental, and social dimensions of urban development through a multistakeholder participatory process that integrates technical, environmental, political, social, and economic interests in the same territory [38].

\subsection{Composite Indices to Measure Sustainable Development}

Settings of indicators for SD have become a fertile ground for evaluation studies on different disciplines [39-41]. The assessment of SD policies can be deemed a multicriteria decision-making problem that requires composite indices to be addressed. The use of composite indices by global institutions during the last decades has increased their acceptance and their interdisciplinary nature [42]. Their benefit is that they can summarize the data and concentrate a large group of dimensions and indicators into a sole number, facilitating comparison, transparency of knowledge and decision-making [43]. However, they should be interpreted with extreme caution [44]. As Greco et al. state, "each approach in every single step has both its benefits and its drawbacks", and it is essential to understand the methodological framework to better design the weighting, aggregation, and robustness steps. There are several methods to build these composite indices [42,45-47], even to measure the SDG [48-50], but all of them have strengths and weaknesses. For this reason, we focus our analysis on the SDG Index methodology, created by independent scientists and endorsed by the United Nations for its consistency, 'dynamic' distance-to-target assessment, and the possibility to be applied at national, regional, and 
local levels [51]. The advantages of this methodology compared to those of OCDE [52], Eurostat [53], or ASviS [54] are analyzed in Lafortune et al. [48].

Regarding SD composite indices, most of them include the economic, social, environmental, and governance dimensions [2,55-57] through the application of normalization, weighting, and aggregation methods [42,44]. However, the governance facet reflects certain specific features in comparison to the other three dimensions. For instance, the Global Indicator Framework (GIF) proposed in 2015 by the Inter-agency and Expert Group on SDG Indicators (IAEG-SDG) only encompasses $20 \%$ of the indicators to measure SDG16 and SDG17, which are related to the governance dimension. This percentage decreased up to $12 \%$ in the E-Handbook on SDG Indicators [58]. Similarly, the weighting factor of indicators in the SDG Index connected to the governance dimension ranges $11-14 \%$ in country-level SDG reports, and 7-9.5\% in city-level SDG reports [59].

\section{Materials and Methods}

Different sources provided data used in this research. First, the baseline of our study is the information included in the report on the achievement of the SDG at city level elaborated by REDS in 2018 [14]. REDS applies the same methodology to evaluate the SDG performance of Spanish countries and cities. The report covers a sample of 100 mediumsized cities (municipalities with more than 80,000 inhabitants) that represent almost half of the Spanish population and provides information on 85 SDG indicators. Alas, the report does not show single values for each city. Therefore, it has been necessary to conduct several methodological steps to rank each city in terms of SD performance and analyze variations depending on the weight allocated to the governance dimension.

Secondly, the accuracy of the REDS governance indicators was appraised by adopting the operational notion of governance proposed by Glass and Newig [3], which is aligned to the Sustainable Governance Indicators published by the Bertelsmann Stiftung since 2017. This proposal includes the indicator 'Strategic Planning', which was omitted in the REDS report. Herein, we have built the indicator 'Strategic Culture', which accounts for the strategic planning processes carried out in the 100 Spanish cities. Needed information to feed this indicator was gathered from (i) the Inventory of Urban Strategic Plans in Spain (1996-2016) elaborated by Ebrópolis [60]; (ii) two studies conducted in 2003 and 2005 about implementation of the Local Agenda 21 in Spain [61]; and (iii) the repository of the Spanish Network of Urban Initiatives (RIU) that embeds EU-funded programs on Integrated Sustainable Urban Development (2007-2020) [62]. All this information has been merged in an Excel spreadsheet.

The methodological sequence followed to conduct the research is shown in Figure 1, and is based on four operational steps aimed at developing a series of assessment tools to be described in the next subsections.

\subsection{Constrution of the REDS-SDG Index (IR)}

In the first stage, a value is assigned to each one of the 100 cities to elaborate a 'baseline' ranking. The REDS report provides values for each SDG, but not at the city level. We have therefore elaborated a composite index named REDS SDG Index (IR) that assigns a synthetic value of the performance on SDGs to each city to overcome this issue.

IR is fed by the normalized data of REDS and aggregates the 17 SDG in an arithmetic mean. The same methodology developed by SDSN in the SDG Index and Dashboard Reports [63-68] was implemented to normalize and aggregate the 17 SDG. Consequently, the same weighting factor $(1 / 17)$ has been applied to each one to define $\mathrm{IR}_{\mathrm{i}}$ as a normalized index associated to each city $i$ according to Equation (1). The number of cities $i$ ranges from 1 to 100 , where 1 is the lowest value and 100 is the highest score. For each goal $j, j \in\{1,2$, $\left.\ldots, N_{j}\right\}$ and for each indicator $k, k \in\left\{1,2, \ldots, N_{k}\right\}$.

$$
I R_{i}\left(N_{j}, N_{k}, I_{i j k}\right)=\frac{1}{N_{i}} \sum_{j=1}^{N_{j}} \frac{1}{N_{i j}} \sum_{K=1}^{N_{k}} I_{i j k}
$$


where:

$N_{j}$ is the number of the goals ${ }_{j}$ for which data in cities ${ }_{i}$ are available.

$N_{k}$ is the number of indicators ${ }_{k}$ for goals $_{j}$ of each ${ }_{i}$ city.

$I_{i j k}$ is the normalized score for the city ${ }_{i}$ for goals ${ }_{j}$ and indicators ${ }_{k}$.

Methodological development

(a) To assess the governance
dimension in the frame of
the 2030 Agenda
(b) To compare the
performance of the 100
Spanish cities selected by
(c) To assess the accuracy of
governance indicators
selected by REDS
(d) To explore the relationship
between governance and
SD

Figure 1. Research methodology.

\subsection{Development of the Dimensional SDG Index (ID)}

The second step consists of elaborating a 'corrected' ranking of the 100 cities to address the disparity revealed in the assignment of weight values to the SDGs linked to the governance dimension. Whilst the 2030 Agenda allocated a value of 2/17 for SDG 16 and SDG 17, each of the other three sustainable dimensions received a weight of 5/17. This assumption is contradictory to the balanced importance of all four dimensions [69] and confirms the underestimation of the governance dimension in the SDG indices. A second composite index called Dimensional SDG Index (ID) was designed to correct this imbalance and to enable comparison among the performance of SD dimensions by city, unlike IR. ID is built upon IR values that have been regrouped into four sub-indices: Ipe (Social), Ipa (Environment), Ipo (Prosperity), and Igo (Governance), as reflected in Table 1.

Table 1. Distribution of the SDG between the four-dimensional sub-indices.

\begin{tabular}{ccccc}
\hline SD Dimension & Social & Economic & Environmental & Governance \\
\hline 2030 Agenda pillar & People & Prosperity & Planet & Peace \& Partnership \\
Distribution of the SDG & $1-5$ & $7-11$ & $6,12-15$ & 16,17 \\
$\begin{array}{c}\text { Dimensional SDG Index } \\
\text { (ID) Sub-indices }\end{array}$ & Ipe & Ipo & Ipa & Igo \\
\hline
\end{tabular}

Hence, ID seeks to statistically correct the underestimation of the governance dimension attributing the same weighting factor $(1 / 4)$ to each of the four dimensions. Under this premise, ID aggregates the values of its four sub-indices (Ipo, Ipe, Ipa, Igo) by applying the same SDSN methodology. Equations (2)-(6) show how $\mathrm{ID}_{\mathrm{i}}$ has been elaborated for each goal $j, j \in\left\{1,2, \ldots, N_{j}\right\}$ and for each indicator $k, k \in\left\{1,2, \ldots, N_{k}\right\}$ in cities $i, 1<i<100$ :

$$
I D_{i}\left(N_{j}, N_{k}, I_{i j k}\right)=\frac{1}{4} I p e+\frac{1}{4} I p a+\frac{1}{4} I p o+\frac{1}{4} \operatorname{Igo}
$$


Where,

$$
\begin{gathered}
\text { Ipe }=\frac{1}{N_{j}} \sum_{j=1}^{5} \frac{1}{N_{k}} \sum_{K=1}^{N_{k}} I_{i j k} \\
I p a=\frac{1}{N_{j}}\left(\sum_{j=6}^{6} \frac{1}{N_{k}} \sum_{K=1}^{N_{k}} I_{i j k}+\sum_{j=12}^{15} \frac{1}{N_{k}} \sum_{K=1}^{N_{k}} I_{i j k}\right) \\
\text { Ipo }=\frac{1}{N_{j}} \sum_{j=7}^{11} \frac{1}{N_{k}} \sum_{K=1}^{N_{k}} I_{i j k} \\
I g o=\frac{1}{N_{j}} \sum_{j=16}^{17} \frac{1}{N_{k}} \sum_{K=1}^{N_{k}} I_{i j k}
\end{gathered}
$$

In addition,

$N_{j}$ is the number of goals ${ }_{j}$ for which the cities ${ }_{i}$ have data of each SDG subgroup.

$N_{k}$ is the number of indicator ${ }_{k}$ for goals ${ }_{j}$ of each city ${ }_{i}$.

$I_{i j k}$ is the normalized score of indicator ${ }_{k}$ under goals ${ }_{j}$ for cities ${ }_{i}$.

Ipe is the index of goals $j$ related to social development (persons)

$I p a$ is the index of goals $j$ related to environmental development (planet)

Ipo is the index of goals $j$ related to economic development (prosperity)

Igo is the index of goals $j$ related to governance development (peace and partnerships).

\subsection{Operational Notion of Governance}

In the third step, we examine the suitability of the governance indicators selected by REDS, since the underestimation of the governance dimension can be also related to the type of indicators. REDS measures governance through the following indicators:

(a) Money laundering and drug trafficking

(b) Homicides and murders

(c) Municipal transparency index

(d) Electoral participation

(e) Violence against minors

(f) Cooperation and development projects

(g) National networks

(h) Solidity and autonomy of the municipal institution

To assess the accuracy of these indicators, we contrast them with those embedded in the operational notion of governance proposed by Glass and Newig [3] in Table 2. The aim

\begin{tabular}{|c|c|c|}
\hline Variable & Description & Indicators \\
\hline 1. Participation & $\begin{array}{l}\text { The capability of economic and non-economic interest } \\
\text { groups to propose and assess relevant policy measures } \\
\text { and their implementation. }\end{array}$ & $\begin{array}{l}\text { 1.1. Association competence (business) } \\
\text { 1.2. Association competence (others) }\end{array}$ \\
\hline 2. Policy coherence & $\begin{array}{l}\text { The extent to which the institutional structure fosters } \\
\text { coherent and coordinated policy making } \\
\text { and implementation }\end{array}$ & $\begin{array}{l}\text { 2.1 Inter-ministerial coordination } \\
\text { 2.2. Coherent communication } \\
\text { 2.3 Institutional coherence for implementation }\end{array}$ \\
\hline $\begin{array}{l}\text { 3. Reflexivity } \\
\text { and adaptation }\end{array}$ & $\begin{array}{l}\text { The degree of reflexivity and adaptation of institutional } \\
\text { arrangements including self-monitoring, capacity for } \\
\text { reform, the influence of strategic planning units, and } \\
\text { regulatory impact assessments. }\end{array}$ & $\begin{array}{l}\text { 3.1. Organizational reform } \\
\text { 3.2. Adaptability } \\
\text { 3.3. Strategic Planning } \\
\text { 3.4 Evidence-based instruments }\end{array}$ \\
\hline $\begin{array}{l}\text { 4. Democratic } \\
\text { institutions }\end{array}$ & $\begin{array}{l}\text { The quality of democratic institutions including electoral } \\
\text { process, media freedom and access to information, civil } \\
\text { rights, and political liberties, as well as rule of law. }\end{array}$ & $\begin{array}{l}\text { 4.1. Electoral process } \\
\text { 4.2 Access to information } \\
\text { 4.3. Civil rights and political liberties } \\
\text { 4.4. Rule of law }\end{array}$ \\
\hline
\end{tabular}
is to evaluate the correspondence between them. For example, (c) Municipal transparency index matches with 4.2. Access to information.

Table 2. Operational definition of governance and indicators proposed by Glass and Newig [3]. 


\subsection{Elaboration of the Strategic Culture Indicator (Icu)}

In the search for more accurate governance indicators, the fourth phase is focused on developing a new governance indicator. Since strategic planning processes support SD policies, we assume they can provide information about the relational and organizational dynamics of territories, particularly at the local level. Furthermore, there is a long tradition of implementation of strategic planning processes in Europe. Based on those assumptions, we build the indicator 'Strategic Culture' (Icu). Icu measures the variety of urban strategic processes that have taken place in a territory over time according to the Integrated Sustainable Urban Development (ISUD) approach. Besides, this metric is especially suitable in the case of Spain, where cities have put into practice those processes since the 1990s [38,61].

A new ranking of cities based on this new indicator was devised. Furthermore, Icu allows clustering of the 100 cities depending on two parameters: duration (years) and variety of instruments $(n)$. For the duration, we have established 13 years of experience in strategic planning as the cut-off value, which corresponds approximately to the middle point of a term of 30 years, the average time taken by European strategic planning initiatives. In this vein, the sample was divided into two groups. The variety of instruments $(n)$ comprises the local strategic planning processes in the 100 cities such as (1) Local Agenda 21 [38,61], (2) Urban Strategic Plans [37,60], (3) URBANA Initiative 2007-13, and (4) EDUSI $2014-20[39,62]$. They are scored in a range from 0 to 4 processes. The combination of both parameters allows clustering the 100 Spanish cities in 7 groups that reflect the value of 'Strategic Culture' from 1 to 7 , as represented in Table 3.

Table 3. Values of the Strategic Culture indicator (Icu).

\begin{tabular}{ccccc}
\hline Group & Icu & Value & Duration (years) & Instruments (n) \\
\hline 1 & 7 & $>13$ & 4 \\
2 & 6 & $>13$ & 3 \\
3 & 5 & $>13$ & 2 \\
4 & 4 & $<13$ & 3 \\
5 & 3 & $<13$ & 2 \\
6 & 2 & $<13$ & 1 \\
7 & 1 & $<13$ & 0 \\
\hline
\end{tabular}

\section{Results}

In this section, we summarize the main results according to the methodological sequence previously described.

\subsection{Baseline Ranking of 100 Cities upon IR: SD Performance Is Midway}

The baseline ranking of SD performance for the 100 Spanish cities is based on the values provided by IR as illustrated in Table 4 . The higher IR value (60.54) corresponds to the first position, whilst the lower value (40.95) is assigned to the last position. The average IR is 50.12 .

\subsection{Corrected Ranking of 100 Cities upon ID: Better Governance Triggers Better SD Performance}

The dimensional index ID ranks the 100 Spanish cities by assigning the same weighting factor to the four SD dimensions. As a result, the arithmetic mean (50.58) remains almost the same, but the range of values increases (63.09 to 39.36). The position of cities (P) with respect to IR (Table 5) is amended.

The positive relationship between the values of the governance dimension (measured by subindex Igo) and the variation of cities' position (cities with better values in Igo improve their position much more compared to those ones with lower values of governance) are the most outstanding findings. Data by indices and subindices are summarized in Table A1 of the Appendix A. 
Table 4. Baseline ranking of 100 cities according to IR values.

\begin{tabular}{|c|c|c|c|c|c|}
\hline Position IR & City & $\mathrm{IR} \geq \mathbf{5 0}$ & Position IR & City & IR $<50$ \\
\hline 1 & Vitoria-Gasteiz & 60.54 & 50 & Parla & 49.95 \\
\hline 2 & Pozuelo de Alarcón & 58.69 & 51 & Las Palmas de Gran Canaria & 49.85 \\
\hline 3 & Las Rozas de Madrid & 57.11 & 52 & Sabadell & 49.62 \\
\hline 4 & Alcobendas & 56.74 & 53 & Córdoba & 49.60 \\
\hline 5 & Madrid & 56.66 & 54 & Granada & 49.60 \\
\hline 6 & Alcorcón & 56.31 & 55 & Orense & 49.55 \\
\hline 7 & Getafe & 55.76 & 56 & Toledo & 49.54 \\
\hline 8 & Logroño & 55.75 & 57 & Badajoz & 49.27 \\
\hline 9 & Soria & 55.60 & 58 & Segovia & 49.22 \\
\hline 10 & San Cugat del Vallés & 55.45 & 59 & Cuenca & 49.06 \\
\hline 11 & Rivas-Vaciamadrid & 55.44 & 60 & Hospitalet de Llobregat & 49.04 \\
\hline 12 & Fuenlabrada & 55.35 & 61 & Cádiz & 49.00 \\
\hline 13 & Donostia/San Sebastián & 55.23 & 62 & Jaén & 48.91 \\
\hline 14 & Burgos & 54.80 & 63 & León & 48.80 \\
\hline 15 & San Sebastián de los Reyes & 54.75 & 64 & Badalona & 48.69 \\
\hline 16 & Leganés & 54.63 & 65 & Salamanca & 48.66 \\
\hline 17 & Ávila & 54.52 & 66 & Marbella & 48.16 \\
\hline 18 & Alcalá de Henares & 54.31 & 67 & Valencia & 48.07 \\
\hline 19 & Huesca & 54.18 & 68 & Alicante & 47.97 \\
\hline 20 & Santander & 53.94 & 69 & Pontevedra & 47.82 \\
\hline 21 & Coslada & 53.85 & 70 & Vigo & 47.76 \\
\hline 22 & Móstoles & 53.54 & 71 & Reus & 47.58 \\
\hline 23 & Zaragoza & 53.34 & 72 & Telde & 47.46 \\
\hline 24 & Pamplona/Iruña & 53.28 & 73 & Santa Coloma de Gramanet & 47.45 \\
\hline 25 & Girona & 53.06 & 74 & Huelva & 47.44 \\
\hline 26 & Cáceres & 52.92 & 75 & Valladolid & 47.36 \\
\hline 27 & Albacete & 52.83 & 76 & Mataró & 47.35 \\
\hline 28 & Bilbao & 52.63 & 77 & Cartagena & 47.02 \\
\hline 29 & Palma & 52.48 & 78 & La Coruña & 46.89 \\
\hline 30 & Lugo & 52.12 & 79 & San Fernando & 46.85 \\
\hline 31 & Gijón & 52.01 & 80 & El Puerto de Santa María & 46.53 \\
\hline 32 & Guadalajara & 51.93 & 81 & Málaga & 46.44 \\
\hline 33 & Santiago de Compostela & 51.93 & 82 & Zamora & 46.24 \\
\hline 34 & Oviedo & 51.73 & 83 & Ceuta & 45.71 \\
\hline 35 & Palencia & 51.73 & 84 & Algeciras & 45.33 \\
\hline 36 & Tarrasa & 51.73 & 85 & Melilla & 45.33 \\
\hline 37 & San Cristóbal de La Laguna & 51.63 & 86 & Chiclana de la Frontera & 45.32 \\
\hline 38 & Ciudad Real & 51.47 & 87 & Murcia & 45.31 \\
\hline 39 & Torrejón de Ardoz & 51.33 & 88 & Sevilla & 45.30 \\
\hline 40 & Castellón de la Plana & 51.29 & 89 & Jerez de la Frontera & 45.07 \\
\hline 41 & Lleida & 51.27 & 90 & Roquetas de Mar & 44.81 \\
\hline 42 & Tarragona & 50.94 & 91 & Almería & 44.62 \\
\hline 43 & Avilés & 50.76 & 92 & Lorca & 44.61 \\
\hline 44 & Baracaldo & 50.69 & 93 & Vélez-Málaga & 44.44 \\
\hline 45 & Cornellá de Llobregat & 50.56 & 94 & Torrent & 44.20 \\
\hline 46 & Barcelona & 50.49 & 95 & Elche & 43.96 \\
\hline 47 & San Baudilio de Llobregat & 50.47 & 96 & Dos Hermanas & 43.77 \\
\hline 48 & Santa Cruz de Tenerife & 50.15 & 97 & Talavera de la Reina & 43.47 \\
\hline \multirow{3}{*}{$\begin{array}{l}40 \\
49\end{array}$} & Arona & 50.01 & 98 & Teruel & 42.06 \\
\hline & & & 99 & Torrevieja & 41.85 \\
\hline & & & 100 & El Ejido & 40.95 \\
\hline
\end{tabular}


Table 5. New ranking of the 100 cities' SD performance position (P) according to ID.

\begin{tabular}{|c|c|c|c|c|c|c|c|c|c|}
\hline $\begin{array}{c}\mathbf{P} \\
\text { IR }\end{array}$ & City & $\begin{array}{l}\text { Value } \\
\text { ID }\end{array}$ & $\begin{array}{c}\mathbf{P} \\
\text { ID }\end{array}$ & $\begin{array}{l}\text { Variation } \\
\text { P IR-P ID }\end{array}$ & $\begin{array}{l}\mathbf{P} \\
\mathbf{R}\end{array}$ & City & $\begin{array}{l}\text { Value } \\
\text { ID }\end{array}$ & $\begin{array}{c}\mathbf{P} \\
\text { ID }\end{array}$ & $\begin{array}{l}\text { Variation } \\
\text { P IR-P ID }\end{array}$ \\
\hline 1 & Vitoria-Gasteiz & 63.09 & 1 & 0 & 50 & Parla & 47.29 & 78 & -28 \\
\hline 2 & Pozuelo de Alarcón & 59.59 & 2 & 0 & 51 & Las Palmas de G.C & 49.06 & 61 & -10 \\
\hline 3 & Las Rozas de Madrid & 57.51 & 6 & -3 & 52 & Sabadell & 49.60 & 56 & -4 \\
\hline 4 & Alcobendas & 57.18 & 9 & -5 & 53 & Córdoba & 51.90 & 42 & 11 \\
\hline 5 & Madrid & 57.77 & 4 & 1 & 54 & Granada & 50.31 & 51 & 3 \\
\hline 6 & Alcorcón & 56.70 & 11 & -5 & 55 & Orense & 49.81 & 54 & 1 \\
\hline 7 & Getafe & 56.58 & 2 & -5 & 56 & Toledo & 51.25 & 47 & 9 \\
\hline 8 & Logroño & 58.72 & 3 & 5 & 57 & Badajoz & 48.58 & 65 & -8 \\
\hline 9 & Soria & 57.58 & 5 & 4 & 58 & Segovia & 52.41 & 40 & 18 \\
\hline 10 & San Cugat del Vallés & 56.79 & 10 & 0 & 59 & Cuenca & 50.53 & 50 & 9 \\
\hline 11 & Rivas-Vaciamadrid & 55.28 & 16 & -5 & 60 & Hospitalet de Llobregat & 49.97 & 53 & 7 \\
\hline 12 & Fuenlabrada & 54.48 & 25 & -13 & 61 & Cádiz & 48.58 & 66 & -5 \\
\hline 13 & Donostia/San Sebastián & 57.44 & 7 & 6 & 62 & Jaén & 47.64 & 75 & -13 \\
\hline 14 & Burgos & 57.25 & 8 & 6 & 63 & León & 50.64 & 49 & 14 \\
\hline 15 & S.S. de los Reyes & 54.87 & 19 & -4 & 64 & Badalona & 48.24 & 67 & -3 \\
\hline 16 & Leganés & 54.95 & 18 & -2 & 65 & Salamanca & 49.49 & 58 & 7 \\
\hline 17 & Ávila & 55.70 & 15 & 2 & 66 & Marbella & 48.76 & 64 & 2 \\
\hline 18 & Alcalá de Henares & 54.10 & 28 & -10 & 67 & Valencia & 47.80 & 74 & -7 \\
\hline 19 & Huesca & 55.04 & 17 & 2 & 68 & Alicante & 49.56 & 57 & 11 \\
\hline 20 & Santander & 56.15 & 13 & 7 & 69 & Pontevedra & 48.90 & 63 & 6 \\
\hline 21 & Coslada & 52.62 & 38 & -17 & 70 & Vigo & 49.40 & 59 & 11 \\
\hline 22 & Móstoles & 53.11 & 33 & -11 & 71 & Reus & 47.83 & 71 & 0 \\
\hline 23 & Zaragoza & 56.03 & 14 & 9 & 72 & Telde & 42.89 & 95 & -23 \\
\hline 24 & Pamplona/Iruña & 54.43 & 26 & -2 & 73 & Santa Coloma de Gramanet & 46.98 & 80 & -7 \\
\hline 25 & Girona & 54.12 & 27 & -2 & 74 & Huelva & 48.04 & 69 & 5 \\
\hline 26 & Cáceres & 53.60 & 30 & -4 & 75 & Valladolid & 50.14 & 52 & 23 \\
\hline 27 & Albacete & 54.56 & 22 & 5 & 76 & Mataró & 47.38 & 76 & 0 \\
\hline 28 & Bilbao & 54.54 & 23 & 5 & 77 & Cartagena & 47.80 & 77 & 5 \\
\hline 29 & Palma & 52.41 & 41 & -12 & 78 & La Coruña & 47.80 & 73 & 5 \\
\hline 30 & Lugo & 52.94 & 35 & -5 & 79 & San Fernando & 44.90 & 87 & -8 \\
\hline 31 & Gijón & 53.76 & 29 & 2 & 80 & El Puerto de Santa María & 45.65 & 83 & -3 \\
\hline 32 & Guadalajara & 54.53 & 24 & 8 & 81 & Málaga & 47.11 & 79 & 2 \\
\hline 33 & Santiago de Compostela & 52.63 & 37 & -4 & 82 & Zamora & 47.31 & 77 & 5 \\
\hline 34 & Oviedo & 54.78 & 20 & 14 & 83 & Ceuta & 42.75 & 96 & -13 \\
\hline 35 & Palencia & 54.65 & 21 & 14 & 84 & Algeciras & 43.07 & 94 & -10 \\
\hline 36 & Tarrasa & 52.67 & 36 & 0 & 85 & Melilla & 40.77 & 99 & -14 \\
\hline 37 & S. Cristóbal de La Laguna & 51.87 & 43 & -6 & 86 & Chiclana de la Frontera & 44.55 & 88 & -2 \\
\hline 38 & Ciudad Real & 52.99 & 34 & 4 & 87 & Murcia & 48.07 & 68 & 19 \\
\hline 39 & Torrejón de Ardoz & 49.76 & 55 & -16 & 88 & Sevilla & 46.93 & 81 & 7 \\
\hline 40 & Castellón de la Plana & 53.33 & 32 & 8 & 89 & Jerez de la Frontera & 43.71 & 91 & -2 \\
\hline 41 & Lleida & 53.38 & 31 & 10 & 90 & Roquetas de Mar & 45.12 & 85 & 5 \\
\hline 42 & Tarragona & 52.44 & 39 & 3 & 91 & Almería & 43.67 & 92 & -1 \\
\hline 43 & Avilés & 51.72 & 44 & -1 & 92 & Lorca & 45.00 & 86 & 6 \\
\hline 44 & Baracaldo & 49.35 & 60 & -16 & 93 & Vélez-Málaga & 43.53 & 93 & 0 \\
\hline 45 & Cornellá de Llobregat & 51.20 & 48 & -3 & 94 & Torrent & 45.35 & 84 & 10 \\
\hline 46 & Barcelona & 51.40 & 46 & 0 & 95 & Elche & 46.32 & 82 & 13 \\
\hline 47 & San Baudilio de Llobregat & 51.65 & 45 & 2 & 96 & Dos Hermanas & 42.62 & 97 & -1 \\
\hline 48 & Santa Cruz de Tenerife & 49.01 & 62 & -14 & 97 & Talavera de la Reina & 44.10 & 90 & 7 \\
\hline \multirow[t]{3}{*}{49} & Arona & 47.86 & 70 & -21 & 98 & Teruel & 44.13 & 89 & 9 \\
\hline & & & & & 99 & Torrevieja & 41.61 & 98 & 1 \\
\hline & & & & & 100 & El Ejido & 39.36 & 100 & 0 \\
\hline
\end{tabular}

Negative values (in red) lose positions in the ranking in contrast to positive values (in blue).

Figure 2 shows this relationship and the changes in the position of cities in relation to IR and ID when values are sorted after updating the governance dimension sub-indice (Igo). Bars in the chart represent the distance between each city when converting the IR synthetic value into ID. The cities with higher values of governance (Igo) have significantly 
improved their ranking in comparison to the ones with lower values as shown in Table A2 of the Appendix A.

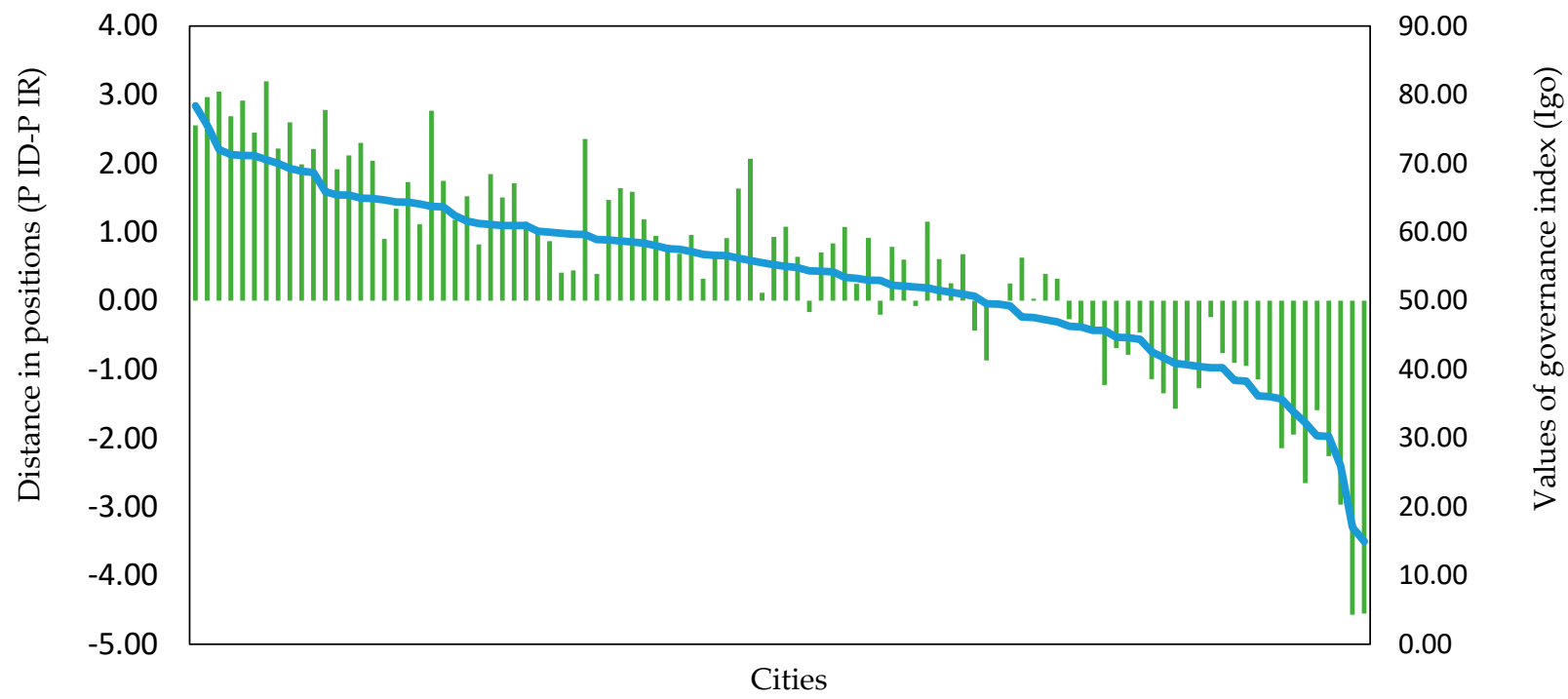

Figure 2. Relation between Governance index (Igo) and changes of position in cities ranking (ID and IR).

\subsection{Assessment of Governance Indicators Used by the REDS: Better Than Others but Still Incomplete}

The set of governance indicators selected by REDS are more adequate than those used by other international reports focused on cities. REDS proposes a greater number of governance indicators $(9.52 \%)$ compared to them, as seen in Table A3 of the Appendix A. However, according to Glass and Newig [3], even if metrics cover a broad range of variables, the governance indicators tied to Policy coherence and Reflexivity and adaptation are lacking. Table 6 displays the results of the assessment performed.

Table 6. Correspondence between indicators proposed by Glass and Newig [3] and indicators of REDS.

\begin{tabular}{|c|c|c|c|}
\hline Variable & Description & Glass and Newig Indicators & REDS Indicators \\
\hline 1. Participation & $\begin{array}{l}\text { The capability of economic and } \\
\text { non-economic interest groups to } \\
\text { propose and assess relevant policy } \\
\text { measures and their implementation. }\end{array}$ & $\begin{array}{l}\text { 1.1. Association } \\
\text { competence (business) } \\
\text { 1.2. Association } \\
\text { competence (others) }\end{array}$ & $\begin{array}{l}\text { 1.2.1. National networks } \\
\text { 1.2.2. Cooperation and } \\
\text { development projects }\end{array}$ \\
\hline $\begin{array}{l}\text { 2. Policy } \\
\text { coherence }\end{array}$ & $\begin{array}{l}\text { The extent to which the institutional } \\
\text { structure fosters coherent and } \\
\text { coordinated policy making } \\
\text { and implementation }\end{array}$ & $\begin{array}{l}\text { 2.1 Inter-ministerial coordination } \\
\text { 2.2. Coherent communication } \\
\text { 2.3 Institutional coherence } \\
\text { for implementation }\end{array}$ & None \\
\hline $\begin{array}{l}\text { 3. Reflexivity } \\
\text { and adaptation }\end{array}$ & $\begin{array}{l}\text { The degree of reflexivity and } \\
\text { adaptation of institutional } \\
\text { arrangements including } \\
\text { self-monitoring, capacity for reform, } \\
\text { the influence of strategic planning units, } \\
\text { and regulatory impact assessments. }\end{array}$ & $\begin{array}{l}\text { 3.1. Organizational reform } \\
\text { 3.2. Adaptability } \\
\text { 3.3. Strategic Planning } \\
\text { 3.4. Evidence-based instruments }\end{array}$ & None \\
\hline $\begin{array}{l}\text { 4. Democratic } \\
\text { institutions }\end{array}$ & $\begin{array}{l}\text { The quality of democratic institutions } \\
\text { including electoral process, media } \\
\text { freedom and access to information, civil } \\
\text { rights, and political liberties, as well as } \\
\text { rule of law. }\end{array}$ & $\begin{array}{l}\text { 4.1. Electoral process } \\
\text { 4.2 Access to information } \\
\text { 4.3. Civil Rights and } \\
\text { Political Liberties } \\
\text { 4.4. Rule of Law }\end{array}$ & $\begin{array}{l}\text { 4.1.1. Electoral participation } \\
\text { 4.2.1. Municipal } \\
\text { transparency index } \\
\text { 4.3.1. Solidity and autonomy of } \\
\text { the municipal institution } \\
\text { 4.4.1. Violence against minors } \\
\text { 4.4.2. Money laundering and } \\
\text { drug trafficking } \\
\text { 4.4.3. Homicides and murders }\end{array}$ \\
\hline
\end{tabular}




\subsection{Ranking of 100 Cities upon Icu: More Experience in Urban Strategic Planning Accelerates SD Performance}

The new indicator Strategic Culture (Icu) fills the gaps showed in Table 6. As such, the 'Reflexivity and adaptation' dimension corresponds to 3.3. Strategic Planning, whilst Icu can be also extended to the 'Policy coherence' domain since strategic planning was originally conceived as a management tool in the private sector.

To validate the indicator, we have analyzed the relationship between the Igo values for the 100 cities and their performance on IR and ID by clustering the cities according to Icu. IR results are inconsistent, since there is no correspondence between Groups 13 (cities more experienced in urban strategic planning processes) and IR performance. However, the correspondence increases when governance is better weighted in ID. With regard to Icu, cities with more experience in urban strategic planning processes (higher Icu value), significantly enhance their position. As the improvement has been measured in percentages, Group 1 cities boost their position in $71.43 \%$ of cases, while cities of Groups 6 and 7 worsen it, by $52.94 \%$ and $55.56 \%$, respectively (Table 7 ).

Table 7. Worse/better \% change of ID ranking.

\begin{tabular}{|c|c|c|c|}
\hline Icu & Cities & Worse & Better \\
\hline Group 1 & Alcobendas; Alicante; Almería; Barcelona; Málaga; Palencia; Sevilla & $28.57 \%$ & $71.43 \%$ \\
\hline Group 2 & $\begin{array}{l}\text { Albacete; Badajoz; Bilbao; Burgos; Cádiz; Córdoba; Elche; Getafe; Hospitalet de } \\
\text { Llobregat; Jerez de la Frontera; La Coruña; Madrid; Murcia; Oviedo; Pamplona/Iruña; } \\
\text { Santa Coloma de Gramanet; Santa Cruz de Tenerife; Santander; Santiago de } \\
\text { Compostela; Talavera de la Reina; Torrent; Valencia; Vélez-Málaga; Vitoria-Gasteiz }\end{array}$ & $37.50 \%$ & $62.50 \%$ \\
\hline Group 3 & Ceuta; Donostia/San Sebastián; Gijón; Lugo; Zaragoza & $40.00 \%$ & $60.00 \%$ \\
\hline Group 4 & $\begin{array}{l}\text { Granada; Huesca; Jaén; Logroño; Roquetas de Mar; Toledo; Torrejón de Ardoz } \\
\text { Alcalá de Henares; Algeciras; Arona; Badalona; Baracaldo; Cartagena; Castellón de la } \\
\text { Plana/Castelló de la Plana; Ciudad Real; Cuenca; Girona; Huelva; Las Palmas de }\end{array}$ & $28.57 \%$ & $71.43 \%$ \\
\hline Group 5 & $\begin{array}{c}\text { Gran Canaria; Leganés; León; Lorca; Mataró; Melilla; Móstoles; Palma; Pontevedra; } \\
\text { Sabadell; Salamanca; San Baudilio de Llobregat; San Cristóbal de La Laguna; } \\
\text { Tarragona; Telde; Teruel; Valladolid; Zamora }\end{array}$ & $48.28 \%$ & $51.72 \%$ \\
\hline Group 6 & $\begin{array}{l}\text { Alcorcón; Ávila; Avilés; Cáceres; Cornellá de Llobregat; Coslada; El Ejido; El Puerto } \\
\text { de Santa María; Guadalajara; Marbella; Parla; Reus; Rivas-Vaciamadrid; San Cugat del } \\
\text { Vallés; San Fernando; Segovia; Soria; Tarrasa; Vigo }\end{array}$ & $52.94 \%$ & $47.06 \%$ \\
\hline Group 7 & $\begin{array}{l}\text { Chiclana de la Frontera; Dos Hermanas; Fuenlabrada; Las Rozas de Madrid; Lleida; } \\
\text { Orense; Pozuelo de Alarcón; San Sebastián de los Reyes; Torrevieja }\end{array}$ & $55.56 \%$ & $44.44 \%$ \\
\hline
\end{tabular}

The cities of Group 1 and a great number of those of Group 2 have long experience in strategic planning and governance processes linked to urban development. For instance, Barcelona, Malaga, and Alcobendas are flagship cities that have experienced a substantial improvement on sustainable development due to these processes. Consequently, it is not surprising that a greater number of cities strengthen their position in the global ranking when referring to ID after rebalancing the governance dimension. On the contrary, cities of Group 7 have barely implemented strategic planning processes over the years.

\section{Discussion}

Many authors argue that the evaluation of multidimensional concepts such as SD through composite indices entails an oversimplification of the aspects to be appraised [44,70], whilst others consider them as the most appropriate instruments to make decisions and visualize the evolution and the impacts of policies [43,71,72]. Multi-Criteria Decision-Making techniques (MCDM) arise as highly suitable in multidimensional frameworks such as SD [73-75]. They enable one to analyze (rank, classify, choose) a series of possible alternatives and take into account different criteria simultaneously. These methods illustrate the complexity in wide-ranging fields, such as competitiveness, governance, environment, press, development, peacefulness, tourism, economy, universities, and so on. El Gibari et al. [42] conducted a literature review of papers published after 2002 in leading inter- 
national journals and classified the MCDM methods into five categories: the elementary methods, the value- and utility-based methods, the outranking relation approach, the data envelopment analysis-based methods, and the distance-functions-based methods. Most maintain that the methodological design of indices, especially in the normalization, aggregation, and robust analysis phases, requires the decisions of policy makers to be reliable [47].

However, since the United Nations and other international organizations have chosen this assessment process for the evaluation of the 2030 Agenda, the selection of the dimensions to be examined, the indicators to be defined, and the methodology for constructing indices must be considered carefully $[50,76]$. In this sense, the work carried out by Lafortune et al. [48] is interesting, comparing the four most recent reports used to measure national progress on the Agenda 2030 elaborated by SDSN, OECD, Eurostat, and ASviS. All underline the need for better data to increase the accuracy of their assessment, but also the necessity of involving experts and 'policy trackers' (entities seeking alternative sources of information) to provide more fine-grained and timely appraisals.

Besides, our empirical analysis shows that the governance dimension is underestimated in SDG composite indices because of two main reasons. On the one hand, governance is not equally weighted in comparison to the other three SD dimensions. On the other hand, the selected governance indicators do not accurately reflect relational dynamics of $\mathrm{SD}$ policies, which are inherent to the notion of governance.

To correct this, we propose two methodological stages. Firstly, the aggregation of the 17 SDG of the 2030 Agenda into four sub-indices that embody the four SD dimensions (Ipe, Ipa, Ipo, Igo) by assigning each of them the same weighting factor (1/4). After applying this method to data from REDS, we disclosed that the relationship between governance (Igo) and SD is positive once the underestimation of the governance has been corrected (Figure 2). Hereby, cities with the highest values in Igo notably improved their position on ID with respect to IR compared to those cities with the lowest values.

It could be argued that, statistically, the greater weighting of governance in the synthetic index automatically implies an improvement in the position of those cities with higher values, but this correlation is not certain when referring to Igo. Results show that governance exponentially increases the SD performance of cities.

Secondly, we point out the need for selecting appropriate governance indicators. According to our evaluation in Table 6, most indicators proposed by REDS are rather government-related, and even if government and governance are interrelated, both notions are distinct. As a prerequisite for successful SD policies [77], the integrated approach implies a mode of governance that benefits partnership and network governance for the mobilization and participation of different actors in collaborative processes [78]. Adequate governance indicators should grasp these relational dynamics that are embedded inter alia, in the frame of strategic planning processes. Therefore, we propose a new governance indicator that accounts for Strategic Culture (Icu) of territories.

The analysis shows that $I c u$ is an adequate indicator that works well. It is built upon three types of strategic planning processes (urban strategic plans, the 21 Local Agenda, and ISUD projects) that have been considered a good example of an integrated approach towards SD at urban level [79]. Furthermore, those processes were also implemented in other European cities [80]. The application of Icu in other contexts is thus viable, but it requires a standardized collection of data to increase reliability and comparability among cases. Finally, Icu demonstrates that cities with higher levels of strategic culture, namely, with more years of experience and strategic planning processes, highly enhance their position regarding SD performance [81]. In this vein, governance can be considered a trigger for both the localization of the 2030 Agenda and Integrated Sustainable Urban Development in the EU zone. 


\section{Conclusions}

The academic literature related to SD policies amounts to a great deal of discursive 'smoke' but little in the way of 'empirical fire' [1]. Therefore, the purpose of our study was to empirically assess the way in which the governance dimension of SD is addressed in the frame of the 2030 Agenda, particularly through the SDG Indices. Using the data provided by the REDS report for 100 Spanish cities, we demonstrated our initial hypothesis about the underestimation of the governance dimension due to two main reasons: firstly, the lower weight assigned to the governance dimension within SDG Indices compared to the other dimensions of sustainability (society, economy, and environment); secondly, a selection of governance indicators that do not grasp the relational dynamics inherent to this notion.

After developing a series of operational steps and specific assessment tools such as IR, ID, and Icu, we can conclude that:

(i) The underestimation of the governance dimension in SDG composite indices is inconsistent with the relevance of governance at the conceptual level in the frame of the 2030 Agenda, since all the four SD dimensions are equally important. As such, a rebalance of the governance dimension is needed when measuring the achievement of the SDGs.

(ii) Although the governance indicators should properly account for the relational and organizational dynamics of territories, indicators that assess both aspects are usually lacking. To correct this, we propose a new indicator of Strategic Culture (Icu) based on the experience of cities in strategic planning processes. The new metric can be included in further REDS reports and also applied to other geographical areas different from Spain.

(iii) The relationship between better governance and SD is positive. Higher values in governance lead to better SD performance. This highlights the relevance of governance in the transition to SD. Governance thus arises as a trigger of urban SD.

We also point out that reports on the analysis of the progress towards the SDGs should not be limited to appraise individually each of the 17 SDGs by discarding the complexity of the governance dimension. In this sense, data availability and an accurate understanding of the notion of governance should be addressed to this end. This research provided empirical evidence about consequences of a misleading definition of governance at the operational level. In addition to 'sustainable development', 'governance' is a multidimensional concept as well.

Finally, alongside the refinement of the proposed methods and their application to other contexts in a standardized manner, the results open future research developments such as the integration of expert opinion and 'policy trackers' in the construction of the SDG Index regarding the limits or thresholds of sustainability for each indicator, to ensure their suitability to different territorial scales. In any case, we expect that our findings are useful not only to strengthen REDS methodology, but to promote a higher consistency in SDSN approaches in accordance with the 2030 Agenda.

Author Contributions: Conceptualization, C.G.-P. and M.G.-M.; methodology, C.G.-P. and M.G.-M.; validation, C.G.-P., M.G.-M., and J.M.D.-S.; formal analysis, C.G.-P. and M.G.-M.; investigation, C.G.-P. and M.G.-M; data curation, C.G.-P. and M.G.-M.; writing-original draft preparation, C.G.-P. and M.G.-M.; writing-review and editing, C.G.-P., M.G.-M., and J.M.D.-S.; visualization, C.G.-P. and M.G.-M; supervision, M.G.-M. and J.M.D.-S.; project administration, C.G.-P.; funding acquisition, J.M.D.-S. All authors have read and agreed to the published version of the manuscript.

Funding: This research received no external funding.

Acknowledgments: The authors would like to thank the reviewers and others who have shared comments on earlier versions of this article.

Conflicts of Interest: The authors declare no conflict of interest. 


\section{Appendix A}

Table A1. Synthetic indices built for the 100 Spanish cities.

\begin{tabular}{|c|c|c|c|c|c|c|}
\hline City & IR & Ipe & Ipa & Ipo & Igo & ID \\
\hline Vitoria-Gasteiz & 60.54 & 58.07 & 61.99 & 53.93 & 78.37 & 63.09 \\
\hline Pozuelo de Alarcón & 58.69 & 59.59 & 68.71 & 45.37 & 64.68 & 59.59 \\
\hline Las Rozas de Madrid & 57.11 & 53.35 & 66.41 & 50.46 & 59.83 & 57.51 \\
\hline Alcobendas & 56.74 & 55.91 & 62.02 & 51.11 & 59.67 & 57.18 \\
\hline Madrid & 56.66 & 54.47 & 60.13 & 52.40 & 64.06 & 57.77 \\
\hline Alcorcón & 56.31 & 53.54 & 63.95 & 50.40 & 58.91 & 56.70 \\
\hline Getafe & 55.76 & 54.41 & 60.63 & 50.04 & 61.22 & 56.58 \\
\hline Logroño & 55.75 & 51.50 & 51.63 & 56.58 & 75.51 & 58.72 \\
\hline Soria & 55.60 & 37.86 & 69.55 & 54.09 & 68.83 & 57.58 \\
\hline San Cugat del Vallés & 55.45 & 54.15 & 56.56 & 52.06 & 64.37 & 56.79 \\
\hline Rivas-Vaciamadrid & 55.44 & 51.68 & 60.99 & 54.10 & 54.34 & 55.28 \\
\hline Fuenlabrada & 55.35 & 52.05 & 62.43 & 53.88 & 49.54 & 54.48 \\
\hline Donostia/San Sebastián & 55.23 & 50.08 & 60.47 & 49.23 & 69.99 & 57.44 \\
\hline Burgos & 54.80 & 45.01 & 55.98 & 56.90 & 71.10 & 57.25 \\
\hline San Sebastián de los Reyes & 54.75 & 52.82 & 60.02 & 51.11 & 55.53 & 54.87 \\
\hline Leganés & 54.63 & 52.11 & 61.98 & 48.95 & 56.75 & 54.95 \\
\hline Ávila & 54.52 & 47.64 & 62.41 & 50.37 & 62.36 & 55.70 \\
\hline Alcalá de Henares & 54.31 & 51.13 & 56.80 & 55.54 & 52.94 & 54.10 \\
\hline Huesca & 54.18 & 45.97 & 61.67 & 52.58 & 59.96 & 55.04 \\
\hline Santander & 53.94 & 42.89 & 59.76 & 53.30 & 68.67 & 56.15 \\
\hline Coslada & 53.85 & 51.08 & 58.89 & 54.84 & 45.67 & 52.62 \\
\hline Móstoles & 53.54 & 54.11 & 56.68 & 51.01 & 50.64 & 53.11 \\
\hline Zaragoza & 53.34 & 48.61 & 52.24 & 52.02 & 71.25 & 56.03 \\
\hline Pamplona/Iruña & 53.28 & 49.27 & 56.19 & 51.32 & 60.93 & 54.43 \\
\hline Girona & 53.06 & 55.61 & 50.78 & 49.97 & 60.12 & 54.12 \\
\hline Cáceres & 52.92 & 47.55 & 57.33 & 52.05 & 57.47 & 53.60 \\
\hline Albacete & 52.83 & 49.06 & 52.19 & 52.64 & 64.35 & 54.56 \\
\hline Bilbao & 52.63 & 54.45 & 46.42 & 51.92 & 65.37 & 54.54 \\
\hline Palma & 52.48 & 49.69 & 59.33 & 48.64 & 51.97 & 52.41 \\
\hline Lugo & 52.12 & 38.94 & 59.06 & 56.20 & 57.57 & 52.94 \\
\hline Gijón & 52.01 & 44.28 & 54.74 & 52.36 & 63.65 & 53.76 \\
\hline Guadalajara & 51.93 & 47.27 & 55.79 & 45.81 & 69.24 & 54.53 \\
\hline Santiago de Compostela & 51.93 & 49.29 & 51.52 & 53.10 & 56.60 & 52.63 \\
\hline Oviedo & 51.73 & 46.90 & 48.08 & 52.11 & 72.01 & 54.78 \\
\hline Palencia & 51.73 & 44.29 & 52.17 & 50.97 & 71.15 & 54.65 \\
\hline Tarrasa & 51.73 & 50.30 & 49.93 & 52.45 & 58.02 & 52.67 \\
\hline San Cristóbal de La Laguna & 51.63 & 47.02 & 64.84 & 42.37 & 53.25 & 51.87 \\
\hline Ciudad Real & 51.47 & 51.33 & 50.12 & 48.89 & 61.60 & 52.99 \\
\hline Torrejón de Ardoz & 51.33 & 47.52 & 60.30 & 50.38 & 40.85 & 49.76 \\
\hline Castellón de la Plana & 51.29 & 46.03 & 52.51 & 49.91 & 64.86 & 53.33 \\
\hline Lleida & 51.27 & 45.37 & 49.42 & 53.38 & 65.37 & 53.38 \\
\hline Tarragona & 50.94 & 49.04 & 49.34 & 50.44 & 60.95 & 52.44 \\
\hline Avilés & 50.76 & 47.67 & 49.23 & 52.84 & 57.15 & 51.72 \\
\hline Baracaldo & 50.69 & 54.18 & 50.48 & 51.01 & 41.71 & 49.35 \\
\hline Cornellá de Llobregat & 50.56 & 49.76 & 48.17 & 52.03 & 54.81 & 51.20 \\
\hline Barcelona & 50.49 & 57.51 & 40.35 & 51.18 & 56.55 & 51.40 \\
\hline San Baudilio de Llobregat & 50.47 & 50.29 & 44.93 & 53.02 & 58.38 & 51.65 \\
\hline Santa Cruz de Tenerife & 50.15 & 46.21 & 63.69 & 43.59 & 42.55 & 49.01 \\
\hline Arona & 50.01 & 39.37 & 71.02 & 45.36 & 35.69 & 47.86 \\
\hline Parla & 49.95 & 48.26 & 56.22 & 52.43 & 32.25 & 47.29 \\
\hline Las Palmas de Gran Canaria & 49.85 & 47.27 & 60.40 & 43.96 & 44.61 & 49.06 \\
\hline Sabadell & 49.62 & 46.65 & 50.24 & 52.00 & 49.50 & 49.60 \\
\hline Córdoba & 49.60 & 45.45 & 53.92 & 43.31 & 64.92 & 51.90 \\
\hline Granada & 49.60 & 51.19 & 52.40 & 43.33 & 54.30 & 50.31 \\
\hline
\end{tabular}


Table A1. Cont.

\begin{tabular}{|c|c|c|c|c|c|c|}
\hline City & IR & Ipe & Ipa & Ipo & Igo & ID \\
\hline Orense & 49.55 & 40.43 & 59.07 & 48.48 & 51.25 & 49.81 \\
\hline Toledo & 49.54 & 51.95 & 50.58 & 41.54 & 60.94 & 51.25 \\
\hline Badajoz & 49.27 & 45.73 & 53.62 & 50.29 & 44.67 & 48.58 \\
\hline Segovia & 49.22 & 39.27 & 50.49 & 49.39 & 70.51 & 52.41 \\
\hline Cuenca & 49.06 & 42.98 & 47.36 & 52.93 & 58.84 & 50.53 \\
\hline Hospitalet de Llobregat & 49.04 & 47.61 & 44.08 & 52.96 & 55.23 & 49.97 \\
\hline Cádiz & 49.00 & 53.58 & 52.43 & 42.10 & 46.19 & 48.58 \\
\hline Jaén & 48.91 & 47.46 & 55.28 & 47.40 & 40.42 & 47.64 \\
\hline León & 48.80 & 44.65 & 50.04 & 46.80 & 61.09 & 50.64 \\
\hline Badalona & 48.69 & 51.20 & 41.29 & 54.78 & 45.70 & 48.24 \\
\hline Salamanca & 48.66 & 41.88 & 55.37 & 46.50 & 54.21 & 49.49 \\
\hline Marbella & 48.16 & 37.91 & 60.88 & 44.11 & 52.14 & 48.76 \\
\hline Valencia & 48.07 & 49.53 & 47.07 & 48.33 & 46.27 & 47.80 \\
\hline Alicante & 47.97 & 45.33 & 46.25 & 48.12 & 58.53 & 49.56 \\
\hline Pontevedra & 47.82 & 45.30 & 45.54 & 49.77 & 55.00 & 48.90 \\
\hline Vigo & 47.76 & 45.67 & 46.08 & 47.14 & 58.69 & 49.40 \\
\hline Reus & 47.58 & 43.73 & 48.85 & 49.48 & 49.24 & 47.83 \\
\hline Telde & 47.46 & 46.16 & 65.58 & 42.84 & 16.99 & 42.89 \\
\hline Santa Coloma de Gramanet & 47.45 & 49.22 & 45.34 & 49.00 & 44.37 & 46.98 \\
\hline Huelva & 47.44 & 48.02 & 48.33 & 44.34 & 51.48 & 48.04 \\
\hline Valladolid & 47.36 & 46.40 & 36.11 & 52.18 & 65.88 & 50.14 \\
\hline Mataró & 47.35 & 46.79 & 42.78 & 52.41 & 47.56 & 47.38 \\
\hline Cartagena & 47.02 & 44.59 & 49.28 & 45.10 & 52.25 & 47.80 \\
\hline La Coruña & 46.89 & 43.55 & 49.33 & 45.35 & 52.98 & 47.80 \\
\hline San Fernando & 46.85 & 52.02 & 51.58 & 42.16 & 33.86 & 44.90 \\
\hline El Puerto de Santa María & 46.53 & 46.33 & 54.40 & 41.21 & 40.68 & 45.65 \\
\hline Málaga & 46.44 & 48.80 & 44.68 & 44.03 & 50.94 & 47.11 \\
\hline Zamora & 46.24 & 37.91 & 49.02 & 48.92 & 53.39 & 47.31 \\
\hline Ceuta & 45.71 & 50.33 & 52.21 & 42.52 & 25.92 & 42.75 \\
\hline Algeciras & 45.33 & 48.42 & 51.02 & 42.59 & 30.25 & 43.07 \\
\hline Melilla & 45.33 & 45.06 & 55.94 & 47.13 & 14.97 & 40.77 \\
\hline Chiclana de la Frontera & 45.32 & 47.40 & 55.19 & 35.39 & 40.24 & 44.55 \\
\hline Murcia & 45.31 & 45.73 & 42.68 & 40.14 & 63.73 & 48.07 \\
\hline Sevilla & 45.30 & 47.52 & 40.07 & 43.96 & 56.17 & 46.93 \\
\hline Jerez de la Frontera & 45.07 & 46.93 & 52.62 & 39.27 & 36.03 & 43.71 \\
\hline Roquetas de Mar & 44.81 & 34.66 & 56.06 & 42.86 & 46.92 & 45.12 \\
\hline Almería & 44.62 & 41.18 & 50.00 & 45.20 & 38.29 & 43.67 \\
\hline Lorca & 44.61 & 39.23 & 50.76 & 42.79 & 47.21 & 45.00 \\
\hline Vélez-Málaga & 44.44 & 39.05 & 57.14 & 39.55 & 38.40 & 43.53 \\
\hline Torrent & 44.20 & 41.38 & 47.46 & 40.67 & 51.87 & 45.35 \\
\hline Elche & 43.96 & 37.63 & 42.64 & 45.34 & 59.65 & 46.32 \\
\hline Dos Hermanas & 43.77 & 48.78 & 40.05 & 45.52 & 36.13 & 42.62 \\
\hline Talavera de la Reina & 43.47 & 39.79 & 50.38 & 38.58 & 47.64 & 44.10 \\
\hline Teruel & 42.06 & 41.26 & 27.22 & 52.20 & 55.84 & 44.13 \\
\hline Torrevieja & 41.85 & 35.31 & 49.99 & 40.88 & 40.25 & 41.61 \\
\hline El Ejido & 40.95 & 32.60 & 55.55 & 38.96 & 30.34 & 39.36 \\
\hline
\end{tabular}

Table A2. Changes of city ranking positions (P) according to Icu, Igo, IR and ID values.

\begin{tabular}{|c|c|c|c|c|c|c|c|c|c|}
\hline Cities & $I c u$ & P Igo & Igo & P IR & IR & P ID & ID & P IR-ID & \% P Change \\
\hline Palencia & & 5 & 71.15 & 35 & 51.73 & 21 & 54.65 & +14 & \multirow{7}{*}{$\begin{array}{l}28.57 \% \text { (worse) } \\
71.43 \% \text { (better) }\end{array}$} \\
\hline Alcobendas & & 33 & 59.67 & 4 & 56.74 & 9 & 57.18 & -5 & \\
\hline Alicante & & 38 & 58.53 & 68 & 47.97 & 57 & 49.56 & +11 & \\
\hline Barcelona & Group 1 & 46 & 56.55 & 46 & 50.49 & 46 & 51.40 & 0 & \\
\hline Sevilla & & 47 & 56.17 & 88 & 45.30 & 81 & 46.93 & +7 & \\
\hline Málaga & & 66 & 50.94 & 81 & 46.44 & 79 & 47.11 & +2 & \\
\hline Almería & & 90 & 38.29 & 91 & 44.62 & 92 & 43.67 & -1 & \\
\hline
\end{tabular}


Table A2. Cont.

\begin{tabular}{|c|c|c|c|c|c|c|c|c|c|}
\hline Cities & $I c u$ & P Igo & Igo & P IR & IR & P ID & ID & P IR-ID & \% P Change \\
\hline Oviedo & \multirow{23}{*}{ Group 2} & 1 & 72.01 & 34 & 51.73 & 20 & 54.78 & +14 & \multirow{23}{*}{$\begin{array}{l}37.50 \% \text { (worse) } \\
62.50 \% \text { (better) }\end{array}$} \\
\hline Burgos & & 3 & 71.10 & 14 & 54.80 & 8 & 57.25 & +6 & \\
\hline Santander & & 6 & 68.67 & 20 & 53.94 & 13 & 56.15 & +7 & \\
\hline Bilbao & & 11 & 65.37 & 28 & 52.63 & 23 & 54.54 & +5 & \\
\hline Córdoba & & 13 & 64.92 & 53 & 49.60 & 42 & 51.90 & +11 & \\
\hline Albacete & & 15 & 64.35 & 27 & 52.83 & 22 & 54.56 & +5 & \\
\hline Madrid & & 19 & 64.06 & 5 & 56.66 & 4 & 57.77 & +1 & \\
\hline Murcia & & 20 & 63.73 & 87 & 45.31 & 68 & 48.07 & +19 & \\
\hline Getafe & & 21 & 61.22 & 7 & 55.76 & 12 & 56.58 & -5 & \\
\hline Pamplona/Iruña & & 25 & 60.93 & 24 & 53.28 & 26 & 54.43 & -2 & \\
\hline Elche & & 29 & 59.65 & 95 & 43.96 & 82 & 46.32 & +13 & \\
\hline Santiago de Compostela & & 34 & 56.60 & 33 & 51.93 & 37 & 52.63 & -4 & \\
\hline Hospitalet de Llobregat & & 45 & 55.23 & 60 & 49.04 & 53 & 49.97 & +7 & \\
\hline La Coruña & & 50 & 52.98 & 78 & 46.89 & 73 & 47.80 & +5 & \\
\hline Torrent & & 58 & 51.87 & 94 & 44.20 & 84 & 45.35 & +10 & \\
\hline Talavera de la Reina & & 63 & 47.64 & 97 & 43.47 & 90 & 44.10 & +7 & \\
\hline Valencia & & 71 & 46.27 & 67 & 48.07 & 74 & 47.80 & -7 & \\
\hline Cádiz & & 75 & 46.19 & 61 & 49.00 & 66 & 48.58 & -5 & \\
\hline Badajoz & & 76 & 44.67 & 57 & 49.27 & 65 & 48.58 & -8 & \\
\hline S. Coloma de Gramanet & & 79 & 44.37 & 73 & 47.45 & 80 & 46.98 & -7 & \\
\hline Santa Cruz TF & & 81 & 42.55 & 48 & 50.15 & 62 & 49.01 & -14 & \\
\hline Vélez-Málaga & & 82 & 38.40 & 93 & 44.44 & 93 & 43.53 & 0 & \\
\hline Jerez de la Frontera & & 89 & 36.03 & 89 & 45.07 & 91 & 43.71 & -2 & \\
\hline Vitoria & \multirow{6}{*}{ Group 3} & 92 & 78.37 & 1 & 60.54 & 1 & 63.09 & 0 & \multirow{6}{*}{$\begin{array}{l}40.00 \% \text { (worse) } \\
60.00 \% \text { (better) }\end{array}$} \\
\hline Zaragoza & & 4 & 71.25 & 23 & 53.34 & 14 & 56.03 & +9 & \\
\hline San Sebastian & & 8 & 69.99 & 13 & 55.23 & 7 & 57.44 & +6 & \\
\hline Gijón & & 22 & 63.65 & 31 & 52.01 & 29 & 53.76 & +2 & \\
\hline Lugo & & 41 & 57.57 & 30 & 52.12 & 35 & 52.94 & -5 & \\
\hline Ceuta & & 98 & 25.92 & 83 & 45.71 & 96 & 42.75 & -13 & \\
\hline Logroño & \multirow{7}{*}{ Group 4} & 2 & 75.51 & 8 & 55.75 & 3 & 58.72 & +5 & \multirow{7}{*}{$\begin{array}{c}28.57 \% \text { (worse) } \\
71.4 \% \text { (better) }\end{array}$} \\
\hline Toledo & & 28 & 60.94 & 56 & 49.54 & 47 & 51.25 & +9 & \\
\hline Huesca & & 31 & 59.96 & 19 & 54.18 & 17 & 55.04 & +2 & \\
\hline Granada & & 54 & 54.30 & 54 & 49.60 & 51 & 50.31 & +3 & \\
\hline Roquetas de Mar & & 74 & 46.92 & 90 & 44.81 & 85 & 45.12 & +5 & \\
\hline Torrejón de Ardoz & & 84 & 40.85 & 39 & 51.33 & 55 & 49.76 & -16 & \\
\hline Jaén & & 86 & 40.42 & 62 & 48.91 & 75 & 47.64 & -13 & \\
\hline Valladolid & \multirow{20}{*}{ Group 5} & 12 & 65.88 & 75 & 47.36 & 52 & 50.14 & +23 & \multirow{20}{*}{$\begin{array}{l}48.28 \% \text { (worse) } \\
51.72 \% \text { (better) }\end{array}$} \\
\hline Castellón de la Plana & & 16 & 64.86 & 40 & 51.29 & 32 & 53.33 & +8 & \\
\hline Ciudad Real & & 24 & 61.60 & 38 & 51.47 & 34 & 52.99 & +4 & \\
\hline León & & 26 & 61.09 & 63 & 48.80 & 49 & 50.64 & +14 & \\
\hline Tarragona & & 27 & 60.95 & 42 & 50.94 & 39 & 52.44 & +3 & \\
\hline Girona & & 30 & 60.12 & 25 & 53.06 & 27 & 54.12 & -2 & \\
\hline Cuenca & & 36 & 58.84 & 59 & 49.06 & 50 & 50.53 & +9 & \\
\hline Vigo & & 37 & 58.69 & 70 & 47.76 & 59 & 49.40 & +11 & \\
\hline S. Baudilio de Llobregat & & 39 & 58.38 & 47 & 50.47 & 45 & 51.65 & +2 & \\
\hline Leganés & & 44 & 56.75 & 16 & 54.63 & 18 & 54.95 & -2 & \\
\hline Teruel & & 48 & 55.84 & 98 & 42.06 & 89 & 44.13 & +9 & \\
\hline Pontevedra & & 51 & 55.00 & 69 & 47.82 & 63 & 48.90 & +6 & \\
\hline Salamanca & & 55 & 54.21 & 65 & 48.66 & 58 & 49.49 & +7 & \\
\hline Zamora & & 56 & 53.39 & 82 & 46.24 & 77 & 47.31 & +5 & \\
\hline S. Cristóbal La Laguna & & 57 & 53.25 & 37 & 51.63 & 43 & 51.87 & -6 & \\
\hline Alcalá de Henares & & 59 & 52.94 & 18 & 54.31 & 28 & 54.10 & -10 & \\
\hline Cartagena & & 60 & 52.25 & 77 & 47.02 & 72 & 47.80 & +5 & \\
\hline Palma & & 62 & 51.97 & 29 & 52.48 & 41 & 52.41 & -12 & \\
\hline Huelva & & 64 & 51.48 & 74 & 47.44 & 69 & 48.04 & +5 & \\
\hline Móstoles & & 67 & 50.64 & 22 & 53.54 & 33 & 53.11 & -11 & \\
\hline
\end{tabular}


Table A2. Cont.

\begin{tabular}{|c|c|c|c|c|c|c|c|c|c|}
\hline Cities & Icu & P Igo & Igo & P IR & IR & P ID & ID & P IR-ID & \% P Change \\
\hline Sabadell & & 69 & 49.50 & 52 & 49.62 & 56 & 49.60 & -4 & \\
\hline Mataró & & 72 & 47.56 & 76 & 47.35 & 76 & 47.38 & 0 & \\
\hline Lorca & & 73 & 47.21 & 92 & 44.61 & 86 & 45.00 & +6 & \\
\hline Badalona & & 77 & 45.70 & 64 & 48.69 & 67 & 48.24 & -3 & \\
\hline Las Palmas de G.C. & & 80 & 44.61 & 51 & 49.85 & 61 & 49.06 & -10 & \\
\hline Baracaldo & & 83 & 41.71 & 44 & 50.69 & 60 & 49.35 & -16 & \\
\hline Arona & & 93 & 35.69 & 49 & 50.01 & 70 & 47.86 & -21 & \\
\hline Algeciras & & 97 & 30.25 & 84 & 45.33 & 94 & 43.07 & -10 & \\
\hline Telde & & 99 & 16.99 & 72 & 47.46 & 95 & 42.89 & -23 & \\
\hline Melilla & & 100 & 14.97 & 85 & 45.33 & 99 & 40.77 & -14 & \\
\hline Segovia & \multirow{18}{*}{ Group 6} & 7 & 70.51 & 58 & 49.22 & 40 & 52.41 & +18 & \multirow{18}{*}{$\begin{array}{l}52.94 \% \text { (worse) } \\
47.06 \% \text { (better) }\end{array}$} \\
\hline Guadalajara & & 9 & 69.24 & 32 & 51.93 & 24 & 54.53 & +8 & \\
\hline Soria & & 10 & 68.83 & 9 & 55.60 & 5 & 57.58 & +4 & \\
\hline San Cugat del Vallés & & 18 & 64.37 & 10 & 55.45 & 10 & 56.79 & 0 & \\
\hline Ávila & & 23 & 62.36 & 17 & 54.52 & 15 & 55.70 & +2 & \\
\hline Alcorcón & & 35 & 58.91 & 6 & 56.31 & 11 & 56.70 & -5 & \\
\hline Tarrasa & & 40 & 58.02 & 36 & 51.73 & 36 & 52.67 & 0 & \\
\hline Cáceres & & 42 & 57.47 & 26 & 52.92 & 30 & 53.60 & -4 & \\
\hline Avilés & & 43 & 57.15 & 43 & 50.76 & 44 & 51.72 & -1 & \\
\hline Cornellá de Llobregat & & 52 & 54.81 & 45 & 50.56 & 48 & 51.20 & -3 & \\
\hline Rivas-Vaciamadrid & & 53 & 54.34 & 11 & 55.44 & 16 & 55.28 & -5 & \\
\hline Marbella & & 61 & 52.14 & 66 & 48.16 & 64 & 48.76 & +2 & \\
\hline Reus & & 70 & 49.24 & 71 & 47.58 & 71 & 47.83 & 0 & \\
\hline Coslada & & 78 & 45.67 & 21 & 53.85 & 38 & 52.62 & -17 & \\
\hline El Puerto de Santa María & & 85 & 40.68 & 80 & 46.53 & 83 & 45.65 & -3 & \\
\hline San Fernando & & 94 & 33.86 & 79 & 46.85 & 87 & 44.90 & -8 & \\
\hline Parla & & 95 & 32.25 & 50 & 49.95 & 78 & 47.29 & -28 & \\
\hline El Ejido & & 96 & 30.34 & 100 & 40.95 & 100 & 39.36 & 0 & \\
\hline Lleida & \multirow{9}{*}{ Group 7} & 14 & 65.37 & 41 & 51.27 & 31 & 53.38 & +10 & \multirow{9}{*}{$\begin{array}{l}55.56 \% \text { (worse) } \\
44.44 \% \text { (better) }\end{array}$} \\
\hline Pozuelo de Alarcón & & 17 & 64.68 & 2 & 58.69 & 2 & 59.59 & 0 & \\
\hline Las Rozas de Madrid & & 32 & 59.83 & 3 & 57.11 & 6 & 57.51 & -3 & \\
\hline S. Sebastián de los Reyes & & 49 & 55.53 & 15 & 54.75 & 19 & 54.87 & -4 & \\
\hline Orense & & 65 & 51.25 & 55 & 49.55 & 54 & 49.81 & +1 & \\
\hline Fuenlabrada & & 68 & 49.54 & 12 & 55.35 & 25 & 54.48 & -13 & \\
\hline Torrevieja & & 87 & 40.25 & 99 & 41.85 & 98 & 41.61 & +1 & \\
\hline Chiclana de la Frontera & & 88 & 40.24 & 86 & 45.32 & 88 & 44.55 & -2 & \\
\hline Dos Hermanas & & 91 & 36.13 & 96 & 43.77 & 97 & 42.62 & -1 & \\
\hline
\end{tabular}

Table A3. Number of indicators $\left(\mathrm{N}_{\mathrm{k}}\right)$ and weights (WD) assigned to sustainability dimensions by diverse SDG urban indexes in comparison to the 2030 Agenda [23,36,41,42].

\begin{tabular}{|c|c|c|c|c|c|c|c|c|c|}
\hline \multirow[t]{2}{*}{ SDG } & \multirow[t]{2}{*}{ Dimension } & \multicolumn{2}{|c|}{2030 Agenda } & \multicolumn{2}{|c|}{$\begin{array}{l}2018 \text { Spanish SDG } \\
\text { Urban Index (REDS) }\end{array}$} & \multicolumn{2}{|c|}{$\begin{array}{l}2019 \text { US SDG } \\
\text { Urban Index }\end{array}$} & \multicolumn{2}{|c|}{$\begin{array}{l}2019 \text { European SDG } \\
\text { Urban Index }\end{array}$} \\
\hline & & $\mathbf{N}_{\mathbf{k}}$ & WD & $\mathbf{N}_{\mathbf{k}}$ & WD & $\mathbf{N}_{\mathbf{k}}$ & WD & $\mathbf{N}_{\mathbf{k}}$ & WD \\
\hline 1 & Social & 11 & & 3 & & 5 & & 2 & \\
\hline 2 & Social & 13 & & 3 & & 3 & & 1 & \\
\hline 3 & Social & 27 & $32.79 \%$ & 12 & $34.52 \%$ & 7 & & 6 & $33.93 \%$ \\
\hline 4 & Social & 11 & & 5 & & 4 & $38.60 \%$ & 7 & \\
\hline 5 & Social & 14 & & 6 & & 3 & & 3 & \\
\hline 7 & Economic & 6 & & 4 & & 3 & & 2 & \\
\hline 8 & Economic & 16 & & 5 & & 3 & & 3 & \\
\hline 9 & Economic & 12 & $25.11 \%$ & 5 & $35.71 \%$ & 3 & $33.33 \%$ & 6 & $39.29 \%$ \\
\hline
\end{tabular}


Table A3. Cont.

\begin{tabular}{|c|c|c|c|c|c|c|c|c|c|}
\hline \multirow[t]{2}{*}{ SDG } & \multirow[t]{2}{*}{ Dimension } & \multicolumn{2}{|c|}{2030 Agenda } & \multicolumn{2}{|c|}{$\begin{array}{l}2018 \text { Spanish SDG } \\
\text { Urban Index (REDS) }\end{array}$} & \multicolumn{2}{|c|}{$\begin{array}{l}2019 \text { US SDG } \\
\text { Urban Index }\end{array}$} & \multicolumn{2}{|c|}{$\begin{array}{l}2019 \text { European SDG } \\
\text { Urban Index }\end{array}$} \\
\hline & & $\mathbf{N}_{\mathbf{k}}$ & WD & $\mathbf{N}_{\mathbf{k}}$ & WD & $\mathbf{N}_{\mathbf{k}}$ & WD & $\mathbf{N}_{\mathbf{k}}$ & WD \\
\hline 10 & Economic & 10 & & 6 & & 5 & & 1 & \\
\hline 11 & Economic & 14 & & 10 & & 5 & & 10 & \\
\hline 6 & Environment & 11 & & 3 & & 3 & & 1 & \\
\hline 12 & Environment & 12 & & 4 & & 3 & & 4 & \\
\hline 13 & Environment & 6 & $22.67 \%$ & 3 & $20.24 \%$ & 3 & $21.05 \%$ & 1 & $17.86 \%$ \\
\hline 14 & Environment & 10 & & 4 & & 0 & & 0 & \\
\hline 15 & Environment & 12 & & 3 & & 3 & & 4 & \\
\hline 16 & Governance & 22 & & 5 & & 4 & & 5 & \\
\hline 17 & Governance & 25 & $19.43 \%$ & 3 & $9.53 \%$ & 0 & $7.02 \%$ & 0 & $8.92 \%$ \\
\hline Total & 5 & 232 & $100 \%$ & 84 & $100 \%$ & 61 & $100 \%$ & 56 & $100 \%$ \\
\hline
\end{tabular}

\section{References}

1. Jordan, A. The Governance of Sustainable Development: Taking Stock and Looking Forwards. Environ. Plan. C Gov. Policy 2008, 26, 17-33. [CrossRef]

2. Singh, R.K.; Murty, H.; Gupta, S.; Dikshit, A. An overview of sustainability assessment methodologies. Ecol. Indic. 2012, 15, 281-299. [CrossRef]

3. Glass, L.-M.; Newig, J. Governance for achieving the Sustainable Development Goals: How important are participation, policy coherence, reflexivity, adaptation, and democratic institutions? Earth Syst. Gov. 2019, 2, 100031. [CrossRef]

4. WCED. World Commission on Environment and Development. Our Common Future; Oxford University Press: Oxford, UK, 1987; pp. $1-383$.

5. Treib, O.; Bähr, H.; Falkner, G. Modes of governance: Towards a conceptual clarification. J. Eur. Public Policy 2007, 14, 1-20. [CrossRef]

6. Elkington, J.; Henriques, A.; Richardson, J. The Triple Bottom Line, Does It all Add up? In Assessing the Sustainability of Business and CSR, 1st ed.; Henriques, A., Richardson, J., Eds.; Earthscan Publications: London, UK, 2004; pp. 1-16.

7. Lemos, M.C.; Agrawal, A. Environmental Governance. Annu. Rev. Environ. Resour. 2006, 31, 297-325. [CrossRef]

8. Kanie, N.; Zondervan, R.; Stevens, C. Ideas on Governance 'of' and 'for' Sustainable Development Goals: UNU-IAS/POST2015 Conference Report; United Nations University Institute for the Advanced Study of Sustainability: Tokyo, Japan, 2014.

9. UNDP. United Nations Development Programme. Governance for Sustainable Development Integrating Governance in the Post-2015 Development Framework; United Nations: New York, NY, USA, 2014. Available online: https://www.undp.org/content/dam/ undp/library /Democratic\%20Governance/Di---ussion-Paper---Governance-for-Sustainable-Development.pdf (accessed on 9 May 2020).

10. Kroll, C. Sustainable Development Goals: Are the Rich Countries Ready? Bertelsmann Stiftung; Sustainable Development Indicators and Sustainable Development Solutions Network: New York, NY, USA, 2015.

11. Sachs, J.; Schmidt-Traub, G.; Kroll, C.; Durand-Delacre, D.; Teksoz, K. SDG. Index and Dashboards Report 2017; Bertelsmann Stiftung and Sustainable Development Solutions Network: New York, NY, USA, 2017.

12. Sachs, J.D.; Schmidt-Traub, G.; Kroll, C.; Lafortune, G.; Fuller, G. SDG Index and Dashboards Report 2018; Bertelsmann Stiftung and Sustainable Development Solutions Network: New York, NY, USA, 2018.

13. Sachs, J.; Schmidt-Traub, G.; Kroll, C.; Lafortune, G.; Fuller, G. Sustainable Development Report 2020. In Sustainable Development Report 2020; Cambridge University Press (CUP): Cambridge, UK, 2021.

14. Sánchez de Madariaga, I.; García López, J.; Sisto, R. Los Objetivos de Desarrollo Sostenible en 100 Ciudades Españolas. Informe; Red Española para el Desarrollo Sostenible: Madrid, Spain, 2018.

15. Termeer, C.J.; Dewulf, A.; Biesbroek, R. A critical assessment of the wicked problem concept: Relevance and usefulness for policy science and practice. Policy Soc. 2019, 38, 167-179. [CrossRef]

16. Meuleman, L.; Niestroy, I. Common but Differentiated Governance: A Metagovernance Approach to Make the SDGs Work. Sustainability 2015, 7, 12295-12321. [CrossRef]

17. Tosun, J.; Lang, A. Policy integration: Mapping the different concepts. Policy Stud. 2017, 38, 553-570. [CrossRef]

18. Teplanský, M. Cohesion Policy 2021-2027: Sustainable Urban Development-European Urban Initiative. In Proceedings of the UNICA Seminar on Research Policies \& Urban Challenge, Brussels, Belgium, 7 February 2019.

19. Carpenter, J.; González-Medina, M.; Huete García, M.A.; De Gregorio Hurtado, S. Variegated Europeanization and urban policy: Dynamics of policy transfer in France, Italy, Spain, and the UK. Eur. Urban Reg. Stud. 2020, 27, 227-245. [CrossRef]

20. Informal Meeting of Ministers Responsible for Urban Development in the Member States of the EU. Leipzig Charter on Sustainable European Cities. 2007. Available online: http:/ / www.esponontheroad.eu/library,leipzig-charter-on-sustainable-european-cities (accessed on 2 May 2020). 
21. Del Castillo, J.; Haarich, S. Desarrollo Urbano Sostenible Cofinanciado Por el FEDER en España 2014-2020: Directrices Estratégicas y Prioridades de Inversión; Final Report for DG Regio; European Commission: Brussels, Belgium, 2013.

22. Carter, N. The Politics of the Environment, 2nd ed.; Cambridge University Press: Cambridge, UK, 2007.

23. UCLG. United Cities and Local Governments. Towards the localization of the SDGs. Local and Regional Governments' Report to the 2019 HLPF, 3rd ed.; United Cities and Local Governments: Barcelona, Spain, 2019.

24. Albrechts, L. Strategic Spatial Planning Revisited Experiences from Europe. In Proceedings of the 3rd Regional Development and Governance Symposium, Mersin, Turkey, 27-28 October 2008.

25. González-Medina, M. La planificación estratégica de "nueva generación": Cómo evaluar su impacto como instrumento de gobernanza territorial? Geopolítica(s). Rev. Estud. Sobre Espac. Poder 2013, 3, 271-291. [CrossRef]

26. Ioppolo, G.; Cucurachi, S.; Salomone, R.; Saija, G.; Shi, L. Sustainable Local Development and Environmental Governance: A Strategic Planning Experience. Sustainability 2016, 8, 180. [CrossRef]

27. Van den Berg, L.; Van der Meer, J.; Meer, P.; Pol, J. Organizing Capacity and Social Policies in European Cities. Urban Stud. 2003, 40, 1959-1978. [CrossRef]

28. Healey, P. Relational complexity, and the imaginative power of strategic spatial planning. Eur. Plan. Stud. 2006, 14, 525-546. [CrossRef]

29. Albrechts, L. Strategic (Spatial) Planning Re-examined. Environ. Plan. B Plan. Des. 2004, 31, 743-758. [CrossRef]

30. González-Medina, M. Procesos metropolitanos y planificación estratégica en el sur de Europa: Un enfoque de gobernanza territorial. Ciudad. Territ. 2013, 178, 487-499.

31. Albrechts, L.; Balducci, A.; Hillier, J. (Eds.) Situated Practices of Strategic Planning. An International Perspective; Routledge: London, UK, 2016.

32. Muminović, E.; Radosavljević, U.; Beganović, D. Strategic Planning and Management Model for the Regeneration of Historic Urban Landscapes: The Case of Historic Center of Novi Pazar in Serbia. Sustainability 2020, 12, 1323. [CrossRef]

33. Pascual i Esteve, J. La Estrategia de las Ciudades. Planes Estratégicos Como Instrumento: Métodos, Técnicas y Buenas Prácticas; Diputación de Barcelona: Barcelona, Spain, 1997.

34. Fernández Güell, J. Planificación Estratégica de Ciudades (Proyecto E Gestión); Gustavo Gili: Barcelona, Spain, 1997.

35. Martinelli, F. La Pianificazione Strategica in Talia e in Europa. Metodologie ed Esiti a Confronto; Francoangeli: Milano, Italy, 2005.

36. OECD. Centre for Entrepreneurship, SMEs, Regions and Cities, OECD Principles on Urban Policy. 2019. Available online: https:/ / www.oecd.org/cfe/Brochure-OECD-Principles-Urban-Policy.pdf (accessed on 29 March 2021).

37. Fioretti, C.; Pertoldi, M.; Busti, M.; Van Heerden, S. (Eds.) Handbook of Sustainable Urban Development Strategies; EUR 29990 EN; Publications Office of the European Union: Luxembourg, 2020.

38. UCLG, United Cities and Local Governments. Policy Paper on Urban Strategic Planning: Local Leaders Preparing for the Future of Our Cities. 2010. Felicity Carus, Journalist, London. Available online: https://www.citiesalliance.org/sites/default/files/9636672792 _\%28EN\%29_uclg_policy_paper_\%28eng\%29_web.pdf (accessed on 19 May 2021).

39. Boulanger, P.-M. Sustainable development indicators: A scientific challenge, a democratic issue. Surv. Perspect. Integr. Environ. Soc. 2008, 1, 59-73. [CrossRef]

40. Neuman, M.; Churchill, S.W. Measuring sustainability. Town Plan. Rev. 2015, 86, 457-482. [CrossRef]

41. Böhringer, C.; Löschel, A. Computable general equilibrium models for sustainability impact assessment: Status quo and prospects. Ecol. Econ. 2006, 60, 49-64. [CrossRef]

42. El Gibari, S.; Gómez, T.; Ruiz, F. Building composite indicators using multicriteria methods: A review. J. Bus. Econ. 2018, 89, 1-24. [CrossRef]

43. Saltelli, A. Composite Indicators between Analysis and Advocacy. Soc. Indic. Res. 2007, 81, 65-77. [CrossRef]

44. Greco, S.; Ishizaka, A.; Tasiou, M.; Torrisi, G. On the Methodological Framework of Composite Indices: A Review of the Issues of Weighting, Aggregation, and Robustness. Soc. Indic. Res. 2019, 141, 61-94. [CrossRef]

45. Munda, G.; Nardo, M.; Saisana, M.; Srebotnjak, T. Measuring uncertainties in composite indicators of sustainability. Int. J. Environ. Technol. Manag. 2009, 11, 7-26. [CrossRef]

46. Saisana, M.; Saltelli, A.; Tarantola, S. Uncertainty and sensitivity analysis techniques as tools for the quality assessment of composite indicators. J. R. Stat. Soc. Ser. A (Stat. Soc.) 2005, 168, 307-323. [CrossRef]

47. Munda, G.; Saisana, M. Methodological Considerations on Regional Sustainability Assessment Based on Multicriteria and Sensitivity Analysis. Reg. Stud. 2011, 45, 261-276. [CrossRef]

48. Lafortune, G.; Fuller, G.; Schmidt-Traub, G.; Kroll, C. How Is Progress towards the Sustainable Development Goals Measured? Comparing Four Approaches for the EU. Sustainability 2020, 12, 7675. [CrossRef]

49. Costanza, R.; Daly, L.; Fioramonti, L.; Giovannini, E.; Kubiszewski, I.; Mortensen, L.F.; Pickett, K.E.; Ragnarsdottir, K.V.; De Vogli, R.; Wilkinson, R. Modelling and measuring sustainable wellbeing in connection with the UN Sustainable Development Goals. Ecol. Econ. 2016, 130, 350-355. [CrossRef]

50. Miola, A.; Schiltz, F. Measuring sustainable development goals performance: How to monitor policy action in the 2030 Agenda implementation? Ecol. Econ. 2019, 164, 106373. [CrossRef] [PubMed]

51. Devuyst, D. Linking impact assessment and sustainable development at the local level: The introduction of sustainability assessment systems. Sustain. Dev. 2000, 8, 67-78. [CrossRef] 
52. OECD. Measuring Distance to the SDG Targets 2019: An Assessment of Where OECD Countries Stand. 2019. Available online: https://www.oecd.org/sdd/measuring-distance-to-the-sdg-targets-2019-a8caf3fa-en.htm (accessed on 29 April 2021).

53. Eurostat. Sustainable Development in the European Union: Monitoring Report on Progress Towards the SDGs in An EU Context (2019 Edition). 2019. Available online: https:/ / ec.europa.eu/eurostat/web/products-statisticalbooks/-/KS-02-19-165 (accessed on 29 April 2021).

54. ASviS. The European Union and the Sustainable Development Goals. 2020. Available online: https://asvis.it/public/asvis2 / files /Pubblicazioni/Compositi_Europei_ENG_HR.pdf (accessed on 29 April 2021).

55. Gan, X.; Fernandez, I.C.; Guo, J.; Wilson, M.; Zhao, Y.; Zhou, B.; Wu, J. When to use what: Methods for weighting and aggregating sustainability indicators. Ecol. Indic. 2017, 81, 491-502. [CrossRef]

56. Valentin, A.; Spangenberg, J.H. A guide to community sustainability indicators. Environ. Impact. Assess. Rev. 2000, 20, 381-392. [CrossRef]

57. CERM. Council of European Municipalities and Regions' and Centre'd'études et D'expertise sur 'es Risques, L'environnement, La'mobilité et L'aménagement. The Reference Framework for Sustainable Cities (RFSC). Available online: http://rfsc.eu/ (accessed on 29 March 2021).

58. UN United Nations. E-Handbook on Sustainable Development Goals Indicators. 2018. Available online: https://www.un.org/ development/desa/capacity-development/tools/tool/e-handbook-on-sustainable-development-goals-indicators/ (accessed on 9 May 2020).

59. Lafortune, G.; Zoeteman, K.; Fuller, G.; Mulder, R.; Dagevos, J.; Schmidt-Traub, G. The 2019 SDG Index and Dashboards Report for European Cities (Prototype Version). 2019. Sustainable Development Solutions Network (SDSN) and the Bra-bant Center for Sustainable Development (Telos). Available online: https:/ / www.sdgindex.org/reports/sdg-index-and-dashboards-report-foreuropean-cities/ (accessed on 29 March 2021).

60. Ebrópolis. Inventario de Planes Estratégicos Urbanos. Database. 2016. Available online: http://www.ebropolis.es/web/arbol/ interior.asp?idArbol=239\&idNodo=240 (accessed on 9 May 2020).

61. Llamas, R.; García, V.J.; López, F.J. Un análisis institucional de la implantación de la Agenda Local 21 por los ayuntamientos españoles. Rev. Eur. Dir. Econ. Empresa 2005, 14, 9-40.

62. Localizador de Actuaciones Urbanas. Red de Iniciativas Urbanas. Available online: http://apps.fomento.gob.es/riu (accessed on 9 May 2020).

63. Lafortune, G.; Fuller, G.; Moreno, J.; Schmidt-Traub, G.; Kroll, V. SDG Index and Dashboards. Detailed Methodological Paper. Bertelsmann Stiftung and Sustainable Development Solutions Network; Sustainable Development Solutions Network: New York, NY, USA, 2018.

64. Lynch, A.; LoPresti, A.; Fox, C. The 2019 US Cities Sustainable Development Report; Sustainable Development Solutions Network: New York, NY, USA, 2019.

65. Prakash, M.; Teksoz, K.; Espey, J.; Sachs, J.; Shank, M.; Schmidt-Traub, G.U.S. Cities SDG Index Achieving a Sustainable Urban America; Sustainable Development Solutions Network: New York, NY, USA, 2017.

66. Espey, J.; Dahmm, H.; Manderino, L. Leaving No U.S. City Behind: The U.S. Cities Sustainable Development Goals Index. US Cities Index Report; Sustainable Development Solutions Network: New York, NY, USA, 2018.

67. Zoeteman, K.; Slabbekoorn, J.; Mommaas, H.; Dagevos, J.; Smeets, R. Sustainability Monitoring of European Cities: A Scoping Study Prepared in Collaboration with DG Environment for European Green Capital Award Applicants; TELOS: Tilburg, The Netherlands, 2014.

68. Cavalli, L.; Farnia, L.; Lizzi, G.; Romani, I.; Alibegovic, M.; Vergalli, S. The SDSN Italia SDGs City Index Two Years Later: Update Report (July 27, 2020). FEEM Report No. 08-2020. Available online: https://ssrn.com/abstract=3733706 or http: / / dx.doi.org/10.2139/ssrn.3733706 (accessed on 9 May 2020).

69. UN System Staff College. Understanding the Dimensions of Sustainable Development. 2017. Available online: https:// www.unssc.org/news-and-insights/news/understanding-dimensions-sustainable-development-now-available-8-languages / (accessed on 9 May 2020).

70. Böhringer, C.; Jochem, P.E. Measuring the immeasurable-A survey of sustainability indices. Ecol. Econ. 2007, 63, 1-8. [CrossRef]

71. Paruolo, P.; Saisana, M.; Saltelli, A. Ratings and rankings: Voodoo or science? J. R. Stat. Soc. Ser. A (Stat. Soc.) 2012, 176, 609-634. [CrossRef]

72. Singh, R.K.; Murty, H.; Gupta, S.; Dikshit, A. An overview of sustainability assessment methodologies. Ecol. Indic. 2009, 9, 189-212. [CrossRef]

73. Cabello, J.; Navarro, E.; Prieto, F.; Rodríguez, B.; Ruiz, F.L. Multicriteria development of synthetic indicators of the environmental profile of the Spanish regions. Ecol. Indic. 2014, 39, 10-23. [CrossRef]

74. Boggia, A.; Massei, G.; Pace, E.; Rocchi, L.; Paolotti, L.; Attard, M. Spatial multicriteria analysis for sustainability assessment: A new model for decision making. Land Use Policy 2018, 71, 281-292. [CrossRef]

75. Belton, V.; Stewart, T. Multiple Criteria Decision Analysis: An Integrated Approach; Springer Science \& Business Media: Berlin, Germany, 2002.

76. Diaz-Sarachaga, J.M.; Jato-Espino, D.; Castro-Fresno, D. Is the Sustainable Development Goals (SDG) index an adequate framework to measure the progress of the 2030 Agenda? Sustain. Dev. 2018, 26, 663-671. [CrossRef] 
77. De Gregorio Hurtado, S.; González-Medina, M. Understanding the Emergence of the Spanish Urban Agenda: Moving Towards a New Multi-level Urban Policy Scenario? In The Life and Afterlife of Gay Neighborhoods; Springer Science and Business Media LLC: Berlin, Germany, 2019; pp. 21-48.

78. Navarro-Yáñez, C.J.; Rodríguez-García, M.J. Urban policies as multi-level policy mixes. The comparative urban portfolio analysis to study the strategies of integral urban development initiatives. Cities 2020, 102, 102716. [CrossRef]

79. Navarro-Yáñez, C.J.; Rodríguez-García, M.-J.; Guerrero-Mayo, M.J. Evaluating the Quality of Urban Development Plans Promoted by the European Union: The URBAN and URBANA Initiatives in Spain (1994-2013). Soc. Indic. Res. 2019, 149, 215-237. [CrossRef]

80. CEMR. Reference Framework for Sustainable Cities (RFSC). 2017. Available online: https://www.ccre.org/activites/view/25 (accessed on 9 May 2020).

81. Schoon, M.; Cox, M. Collaboration, Adaptation, and Scaling: Perspectives on Environmental Governance for Sustainability. Sustainability 2018, 10, 679. [CrossRef] 